This manuscript has undergone peer-review and has been accepted for publication in the journal Basin Research but has not undergone typesetting by the publisher. The final version is available at the following address: https://doi.org/10.1111/bre.12608 


\title{
1 Reflection Seismic Thermometry
}

\author{
$2 \quad$ Arka Dyuti Sarkar ${ }^{1,2}$
}

3 Mads Huuse ${ }^{1}$

$4 \quad{ }^{2}$ Corresponding author: arkadyuti.sarkar@manchester.ac.uk

$5 \quad{ }^{1}$ Basins Research Group, Department of Earth and Environmental Sciences, University of

6 Manchester, Manchester M13 9PL, United Kingdom

\section{Abstract}

8 The North Viking Graben (NVG) is part of the mature North Sea Basin petroleum province and 9 designated as a major carbon storage basin for NW Europe. It has been extensively drilled 10 over five decades with an abundance of well and seismic data in the public domain. As such

11 it serves as an excellent setting to demonstrate the efficacy of a reflection seismic data led 12 approach to predicting subsurface temperatures using a state-of-the-art full waveform 13 inversion velocity model covering the entire NVG. In a forward modelling approach, an 14 empirical velocity to thermal conductivity transform is used in conjunction with predefined heatflow to predict subsurface temperature. The predefined heatflow parameters are set based on the range of values from previous studies in the area. Abundant well data with 17 bottom hole temperature $(\mathrm{BHT})$ records provide calibration of results. In the second step of inverse modelling, BHT's as well as the velocity derived thermal conductivity are used to evaluate a 1D steady state approximation of Fourier's Law for heatflow. In this way heatflow is estimated over the $12000 \mathrm{~km}^{2}$ model area at a $\mathrm{km}$ scale (lateral) resolution, highlighting

21 lateral variability in comparison to the traditional point-based heatflow datasets. This heatflow is used to condition a final iterative loop of forward modelling to produce a 
23 temperature model that is best representative of the subsurface temperature. Calibration

24 against 139 exploration wells indicate that the predicted temperatures are on average only

$250.6{ }^{\circ} \mathrm{C}$ warmer than the recorded values, with a root mean squared error of $5^{\circ} \mathrm{C}$. BHT for the

26 recently completed Northern Lights carbon capture and sequestration (CCS) well 31/5-7 (Eos)

27 has been modelled to be $97{ }^{\circ} \mathrm{C}$, which is $6{ }^{\circ} \mathrm{C}$ below the recorded $\mathrm{BHT}$. This highlights the

28 applicability of this workflow not only towards enhancing petroleum systems modelling work

29 but also for use in the energy transition and for fundamental scientific purposes.

30 Highlights

- Estimating subsurface temperature using seismic reflection and velocity data

- Empirical velocity thermal conductivity transform

- Tested in the mature northern North Sea, calibrating results against bottom hole temperatures (BHT) from 139 wells

- Inverse modelling allows derivation of laterally varying heat flow at resolution of tens of $\mathrm{km}$ scale

- Blind tested workflow to estimate BHT from Northern Lights CCS exploration borehole $31 / 5-7$ to within $6^{\circ} \mathrm{C}$ of reported BHT

Seismic; velocity modelling; subsurface temperature; heatflow 


\section{Acknowledgement}

42 This project was enabled by generous funding from Arka's parents, to whom the authors are

43 very grateful. Thanks go to CGG for provision of the North Viking Graben dataset and to

44 Schlumberger for provision of Petrel licenses (the software used for modelling). The authors

45 would like to thank Daniel Schmid, Christian Hardwick \& Dave Muirhead for their comments

46 helping to refine and improve the manuscript. Special thanks go to Kofi Owusu for his

47 comments and assistance in modelling remotely during a pandemic. Thanks also go to

48 colleagues at the Basin Research Group for their support and guidance.

49 Data Availability Statement

50 The data that support the findings of this study are available from CGG Services (Norway) AS.

51 Restrictions apply to the availability of these data, which were used under license for this

52 study. Data are available from the author(s) with the permission of CGG Services (Norway)

53 AS. 
54

\section{Introduction}

The importance of understanding the subsurface temperature conditions is manifold. An understanding of the isotherms may help delineate important temperature driven diagenetic boundaries (Bjørlykke et al., 1989). Similarly, it is useful for petroleum exploration as it informs the maturity and types of hydrocarbons to be expected from a given source rock (Allen \& Allen, 2013). Unlike frontier areas where the effectiveness of source rocks may be in doubt, this is not a concern in the North Sea. However, understanding of the present-day subsurface temperature can still prove useful in such a mature basin. An example could include identification of the so called "Golden Zone" thermal window in reservoirs (Nadeau, 2011). Similarly, an improved understanding of subsurface temperature could assist in enhanced oil recovery (EOR) such as when $\mathrm{CO}_{2}$ saturation is used to aid recovery of heavy oils by reducing the density of the latter (Davarpanah \& Mirshekari, 2020). Investigations into geothermal energy also benefit from improved understanding of subsurface temperature conditions (Bonté et al., 2012; Fuchs \& Balling, 2016). The North Sea is one of the world's most prolific and extensively studied petroleum provinces (Copestake et al., 2003; Cornford, 1998; Leadholm et al., 1985; Rüpke et al., 2008). Over the course of the past sixty years numerous oil and gas fields have been discovered, many of which have served as the testing ground for new technologies such as time lapse 4D seismic or EOR (Awan et al., 2006; Landrø et al., 1999). With this history of developing and applying cutting edge methodologies, it is a fitting setting to test the workflow proposed here. This paper proposes and tests a means of utilising reflection seismic data to predict subsurface temperatures. Previous work has demonstrated that a transform based on empirical velocity and thermal conductivity data may be utilised to convert seismic velocities to thermal conductivities (Sarkar, 2020; Sarkar \& 
77 Huuse, 2018). The derived thermal conductivities may be used in conjunction with heatflow data, either from existing open-source data or through modelling of heatflow, to determine subsurface temperatures from Fourier's Law under a steady state condition. There have been numerous studies of the thermal conductivities and heatflow of sediments in the northern North Sea (see Table A.1) (Andrews-Speed et al., 1984; Brigaud et al., 1992; Cornelius, 1975; Evans, 1977; Evans \& Coleman, 1974; Houbolt \& Wells, 1980; Leadholm et al., 1985). However, there seems to be a hiatus in such studies in recent times. Projects such as the Northern Lights carbon capture and sequestration (CCS) project (Cozier, 2019) would benefit greatly from current knowledge of the subsurface thermal domain for full scale CCS.

\subsection{Thermal model fundamentals}

When considering heat in the shallow subsurface it is important to understand the sources of heat. That the interior of the Earth is considerably hotter is known, with surface heatflow distribution closely linked to the upper mantle (Pollack et al., 1993). However $40 \%$ of outward heatflow originates in the thin outer crust (Beardsmore \& Cull, 2001). Primarily this crustal heat generation is from the radioactive decay of unstable isotopes of elements such as uranium, thorium and potassium (in order of heat production) (Mareschal \& Jaupart, 2013). This radioactive heat component is non uniform in the crust due to the variable distribution of radioisotope bearing lithologies within the crust. Oceanic crust for example lacks acidic rocks, which tend to have the highest radioactive heat production, and thus oceanic heatflow has a lower internal heat component (Hasterok et al., 2011). To a lesser extent crustal heating might arise from the frictional heating at faults or from metamorphic processes, which can be either endo- or exothermic in nature (Beardsmore \& Cull, 2001). 
Fluid movement in the subsurface can lead to heatflow perturbations, particularly in young oceanic crust (Lister, 1972). This might be mitigated by either having sufficient sediment cover or distance from the nearest seamount (from where such hydrothermal fluid systems are likely to originate) (Hasterok et al., 2011). Sediment cover and high rates of sedimentation might also impact heatflow conditions in terms of sediment compaction and thermal rebound with corresponding lower heatflow and suppressed thermal gradient seen in locations of high sediment discharge such as the Bay of Bengal (Hasterok et al., 2011).

To understand how subsurface temperature might be modelled in the present day it is important to establish the key thermal boundary conditions and properties. These are heatflow, seabed temperature, thermal conductivity, the resultant geothermal gradient, and subsurface temperature. The link between heatflow, thermal conductivity and geothermal gradient can be represented by the 1D approximation of Fourier's Law (Eq. 1).

$111 \quad$ Equation 1: $\quad q=k \times \frac{d T}{d Z}$

112 Where $q$ is heatflow $\left(\mathrm{mW} \mathrm{m}^{-2}\right)$; $k$ is thermal conductivity $\left(\mathrm{W} \mathrm{m}^{-1} \mathrm{~K}^{-1}\right)$ and $d T / d Z$ is geothermal 113 gradient $\left({ }^{\circ} \mathrm{C} \mathrm{km}^{-1}\right)$ where $\mathrm{Z}$ is positive downwards. To estimate the temperature at a certain 114 depth in the subsurface, the rate of change of temperature with depth, i.e. the geothermal 115 gradient is important. It becomes apparent then that by rearranging Eq. 1, the input 116 parameters necessary to estimate this are heatflow and thermal conductivity.

$117 \quad$ Equation 2: $\quad \frac{d T}{d Z}=\frac{q}{k}$

118 Thermal conductivity is a measure of the ease with which heat may be conducted through a 119 material (Popov et al., 2003) and is thus critical to estimating the thermal structure of the 120 subsurface. Thermal conductivity data from direct measurements are made either in situ 121 through well logs or via direct measurements on recovered samples (Andrews-Speed et al., 
1984; Jorand et al., 2015; Schön, 2015a). Measuring tools include either a needle probe

123 inserted into a sample or a divided bar apparatus (Evans, 1977; Horai, 1982). However, these

124 measurements may suffer from issues that affect both their ease of acquisition and reliability.

125 For example thermal conductivity probes may have poor contact with borehole walls, or the

126 needle probe reading might be affected by the alignment of the mineral fabric (anisotropy) in

127 relation to the needle orientation (Lucazeau et al., 2004; Pribnow et al., 2000). In the case of

128 the divided bar apparatus, sample preparation is a more involved process, with the

129 application of axial load equivalent to hundreds of metres of overburden on samples having

130 the effect of increasing measurements on both dry and saturated samples (Galson et al.,

131 1987). A range of downhole measuring tools may be used to measure thermal conductivity

132 within the borehole however these are discontinuous measurements that are uneconomic

133 (Mielke et al., 2017). As a result there has been considerable thought put towards deriving

134 thermal conductivity from other more easily measured physical properties such as bulk

135 density, porosity or compressional sound wave velocity (Boulanouar et al., 2013; Esteban et

136 al., 2015; Grevemeyer \& Villinger, 2001; Gu et al., 2017; Hartmann et al., 2005; Horai, 1982;

137 Jorand et al., 2015). In the case of velocity, it is found to have similar sensitivity to properties

138 as thermal conductivity (Houbolt \& Wells, 1980). That is, thermal conductivity is primarily

139 affected by the mineral composition, porosity and presence of fractures (Mielke et al., 2017;

140 Pimienta et al., 2018; Zamora et al., 1993). Temperature and pressure also impact thermal

141 conductivity though not as much as the other factors (Leadholm et al., 1985; Lee, 2003).

142 Figure 1: Study area overview 
144 The North Viking Graben (NVG) (Fig. 1) is located in the Northern North Sea between the East

145 Shetland Platform to the West and the Horda Platform to the east, and part of the north 146 western European cratonic block (Brigaud et al., 1992). It is part of the North Sea Graben

147 system (Fig. 2) (Cornford, 1998). It is a Mesozoic rift system, with the rifting in this area having occurred after the Caledonian orogeny (and extensional orogenic collapse), with there being two primary phases of extensional rifting since the Devonian (Fichler et al., 2011; Rüpke et al., 2008; Ziegler, 1992). Primary rifting in the Permian to Early Triassic was followed by a post rift subsidence period ( $N \varnothing t t v e d t$ et al., 1995). The next phase of rifting was from mid Jurassic to early Cretaceous and was also followed by a post rift subsidence period. The rift axis for the Permo-Triassic rifting is believed to be located under the present Horda Platform with the

154 late Jurassic rift axis below the present day Viking Graben (Christiansson et al., 2000). No major tectonic activity is believed to have occurred post Jurassic though there is some conjecture regarding a Tertiary rifting episode (Rüpke et al., 2008) and mid Miocene inversion

157 (Løseth et al., 2013, 2016). The predominant rift direction in the $N$ to NE striking Viking Graben was west-east and northwest-southeast.

The sedimentary record in this area is Devonian and younger. Sand and shales dominate the

160 Triassic to Jurassic basin fill with carbonates and shales predominant in the Cretaceous

161 (Brigaud et al., 1992). Tertiary lithologies consist of shales, silts and sands, with a brief period 162 of Paleocene volcanism marked by the widespread deposition of volcanic tuffs across the basin (Haaland et al., 2000). Crustal basement rocks in this area have a history exceeding one

164 Wilson cycle and trace back to the junction between the Laurentian and Baltican plates, 165 including the opening of the lapetus Ocean, island arc development linked to oceanic 
subduction and the Caledonian orogeny (Fossen et al., 2008; Meert \& Torsvik, 2003). The composition of the basement rocks can be seen to vary from granites underneath the East Shetland Platform to low and intermediate grade metamorphic and metamorphosed sediments below the Viking Graben and Horda Platform (Fichler et al., 2011). Source rocks in the area are predominantly Kimmeridge Clay (shales) that were deposited in

171 the Late Jurassic (Davison \& Underhill, 2012; Gautier, 2005). Abundant reservoir rocks are 172 available in the NVG all of which exist with a variety of trapping mechanisms. These pre rift reservoirs are usually found in tilted fault blocks where fine-grained post rift sedimentary sequences act as seals.

Figure 2: Structural transect

\section{3. Data}

177 The dataset used for the study includes reflection seismic and borehole data.

178 The North Viking Graben 'mega-merge' was acquired by CGG between 2014 and 2016, 179 covering a total area of $35410 \mathrm{~km}^{2}$. This broadband 3D seismic reflection survey of BroadSeis ${ }^{\mathrm{TM}}$ and BroadSource ${ }^{\mathrm{TM}}$ configuration covers the northern North Sea basin and was shot in a northsouth direction, recorded in TWT down to 9 seconds with an acquisition sample interval of 2 ms (Purvis et al., 2018) though for this work the pre-stack depth migrated (PSDM) volume in

183 the depth domain was utilised. The volume has an inline and crossline bin spacing of $6.25 \mathrm{x}$ $18.75 \mathrm{~m}$. A (flip flop) shot point interval of $18.75 \mathrm{~m}$ and a source separation of $37.5 \mathrm{~m}$ gives a nominal common-mid-point (CMP) fold of 106. Twelve streamers were used in total, each $7950 \mathrm{~m}$ long, with 636 channels towed at depths of $7-50 \mathrm{~m}$ (BroadSeis ${ }^{\mathrm{TM}}$ profile).

187 Multiple algorithms were used to remove noise and multiples. Both manual picking and time tomographic inversion (TOMOT) was used to generate velocities with imaging done using 
190 picking helped generate the final stacking velocities (Purvis et al., 2018). The processed PSTM

191 and PSDM cubes underpin the modelling work conducted in this study.

192 The full waveform inversion (FWI) technique aims to produce a high-fidelity subsurface representation of velocity, as the velocity model minimises differences between observed

194 and modelled seismic waveforms within the original raw data (Warner et al., 2013). In making the FWI velocity product, a best guess starting model based on seismic processing velocities is iteratively improved using a sequence of linearized local inversions (Warner et al., 2013). For the CGG NVG survey the fast track velocity product was made from the Dix conversion of root mean squared (RMS) stacking velocities, followed by Kirchhoff depth migration to residual move out (RMO) velocities (CGG, 2019). During the FWI process, the model was subdivided into smaller areas targeting regions of key geology, allowing verification to be conducted (CGG, 2019). Three production runs at ever increasing seismic frequency $(4 ; 5.5$ \& $8 \mathrm{~Hz}$ ) were conducted as part of the FWI model build (CGG, 2019). The final $8 \mathrm{~Hz}$ update produced the velocity model that best follows geological structure and can characterise small scale features such as injectites (CGG, 2019). The FWI model was calibrated using 101 wells with QC checks completed against sonic log data (CGG, 2019). Directorate (NPD) website. This gave access to well reports, mud logs, geological reports, and wireline logging data. Because the FWI volume was already calibrated against downhole sonic

209 velocity data and provided in the depth domain, the primary data of interest for this study were the corrected bottom hole temperatures $(\mathrm{BHT})$ recorded for each well within the

211 thermal model area. Where drill stem test temperature readings are available these have been used in the NPD dataset. Publicly available heatflow data from the International 
213 Heatflow Commission (IHFC) database were used to provide constraint on the heatflow

214 parameter (Gosnold \& Panda, 2002). There is a scarcity of data points covering the model

215 area as seen in Fig. 1b with the nearest offshore data point too distant to confidently

216 interpolate from (Ritter et al., 2004).

\section{4. Methods}

218 The modelling work has been conducted using Schlumberger's Petrel software used for 3D

219 seismic interpretation and to create and manipulate the property volumes and thermal models in this work. Standard seismic interpretation techniques (Cox et al., 2020;

221 Posamentier, 2004), including horizon mapping, surface map creation and seismic attribute extractions were conducted for a structural interpretation of two reference horizons, the seafloor and the Base Cretaceous Unconformity (BCU). The BCU follows the regional stratigraphic framework and serves as a reference horizon, upon which model outputs are overlain as attributes, thus giving a regional context to the results (Evans, 2003). The seafloor is the ceiling for the thermal models, separating the hydrothermal and the geothermal domains. Both horizons were mapped in depth using the 3D reflection seismic data. For the purposes of this work, no other structural interpretation was necessary. Further interpretation or import of grids can of course be done to observe the predicted temperature at desired stratigraphic levels.

231 The workflow utilised in this project is summarised in Fig. 3. It can be broken down into two main components: the forward modelling approach uses the seismic velocity data as the input parameter to model the thermal conductivity and subsurface temperature using constant surface heatflows, which in turn is calibrated against available BHT data; the inverse approach calculates heatflow from the observed BHTs and the thermal conductivity structure. As 
236 heatflow is an important input parameter to model temperature, it becomes possible to 237 update the temperature forward model with the inverse modelling results, and thus validate 238 the final temperature model results, in a manner akin to tomographic update of velocity 239 models (Jones, 2018; Prada et al., 2019).

240 Figure 3: Reflection seismic thermometry workflow 
242 The reflection seismic dataset is a modern broadband seismic survey covering the North

243 Viking Graben (NVG) spanning across parts of the UK and Norwegian continental shelves

244 (UKCS and NCS, respectively). The full waveform inversion (FWI) final velocity model is the key reflection seismic data product underpinning the modelling work.

\subsubsection{Thermal conductivity structure}

This study uses a high-resolution 3D seismic velocity volume and experimental data relating velocity and conductivity with an empirical relationship (Fig. 4). As this project outlines a remote sensing method, direct thermal conductivity measurement is not possible and instead it must be indirectly determined. If the rocks of the subsurface are considered as a multi component system comprised of minerals, texture (of grains, such as their shape and size), porosity and the fluid content, it becomes possible in an ideal scenario to determine the composite effective thermal conductivity from the contribution of each component part using a suitable mixing law or effective medium model (Duffaut et al., 2018; Hartmann et al., 2005; Schön, 2015b). Normally mud logging data (available here from the NPD database) would be utilised to determine the volumetric fraction of each mineral (Brigaud et al., 1990). We, however, are presenting a remote sensing scenario where only the temperature data from wells is being used to correlate the predicted temperatures with.

The elastic properties of the subsurface are well constrained from seismic data (Mavko et al., 2009) and it provides the avenue to the desired thermal structure. To link thermal properties (thermal conductivity) to elastic properties (acoustic velocity), knowledge of their primary controls becomes necessary. Experimental work has shown that these controls include mineral composition, texture, porosity, the presence of fractures and fluid fill (Gegenhuber \& 
Schoen, 2012). It helps to think of porosity as the crucial intermediary in the proposed empirical relationship as there have been studies examining the link between acoustic velocity and porosity (Eberhart-Phillips et al., 1989; Lee, 2003; Velde, 1996); and similarly the relationship between porosity and thermal conductivity (Fuchs \& Förster, 2013; Jorand et al.,

268 2015). By making the direct leap it must be noted that there are inherent assumptions in such an approach. One concern that may arise is the extent to which the variation in the velocity signal solely corresponding to a thermal conductivity variation (as desired) or is it in fact

271 influenced by external factors (for example fluid overpressure). In such an instance, this issue

272 may be obviated by restricting application to regions of hydrostatic fluid pressure only, 273 however it might be the case that slight overpressure would only correspond to a minor 274 increase in velocity (Lee, 2003). While porosity is a crucial intermediary, mineral composition has a dominant impact on thermal conductivity. Argillaceous rocks have lower conductivities than non-argillaceous (quartz rich) rocks for example (Mavko et al., 2009). The more monomineralic a rock, the greater the correlation between velocity and thermal conductivity (Esteban et al., 2015), which alludes to the impact of anisotropy of thermal conductivity.

279 When considering clay rich rocks, they display poorer correlations for thermal conductivity arising from the platy nature of clay grains (versus more rounded sand grains). At greater 281 compaction however, parallel alignment of clay grains could contribute towards lower 282 effective porosities and thus a stronger correlation with both velocity and thermal 283 conductivity (Velde, 1996). With use of this proposed empirical transform expected for both shallow and deep intervals, it is hoped that the variability of clay rich sediment at shallow levels is balanced at deeper levels. 
It must be noted that even the best thermal conductivity models are subject to caveats, either in the form of the inherent assumptions or the specific circumstances where direct relationships might not be as strong.

By including a wide range of studies, covering a wide array of lithologies and settings, it is hoped that the resulting empirical relationship can serve as a robust first order estimate for the varying porosities encountered within any projected study area. Lithologies include clastic sediments (sandstones of varying grain size from fine to coarse; varying mineral content including nearly isotropic clean quartz rich sandstones \& clay rich sandstones); carbonates (limestone; dolomite; marl; etc); mudstones (clay- \& siltstones); and volcanic \& granitic rocks (granite; basalt; gabbro; etc). The sample dataset is limited to wet samples only and measurements taken using transient measurement apparatus such as the optical scanning method (Popov et al., 1999), in order to maintain applicability to fluid filled rocks in the subsurface and parity between data points respectively. Though the study area is dominated by shales, the approach adopted with the empirical relationship is intended to be globally applicable and thus incorporates samples not proportionally dominant in the NVG study. This approach has previously been applied in passive margin settings offshore Namibia and offshore USA (Sarkar \& Huuse, 2018, 2021). Future studies could aim to utilise an edited sample list reflective of the dominant lithologies in the target area. The best fit regression (Fig. 4) through the subset of points is as follows:

Equation 3: $k_{V}=\left(6 \times 10^{-5}\right) V_{p}^{1.3279}$

Figure 4: Empirical transform for velocity and thermal conductivity 
With a highly detailed FWI velocity volume representing the P-wave velocity of the subsurface and a function relating velocity and thermal conductivity, it is possible to convert the FWI

310 velocity volume into a volume of thermal conductivity varying with depth (using Eq. 3). To

311 facilitate the workflow the FWI interval velocity volume was first converted to an average

312 velocity volume in depth below the seabed (as the geotherm starts at seabed) and this in turn

313 allowed the estimation of instantaneous average thermal conductivity as a function of depth

314 in the entire volume.

\subsubsection{Heatflow input scenarios}

In order to determine the geothermal gradient (Eq. 2), information regarding the heatflow in the study area is required alongside thermal conductivity.

318 A priori heatflow values were defined based on a combination of existing literature and data

319 from the IHFC. As seen on Fig. 1b, there is a paucity of IHFC data points in the study area. This leads to examining the published record for maps of heatflow covering the North Sea, and

321 these tend to exist in the form of heatflow estimate grids at regional or global scale. Examining these grids such as Davies (2013) or Lucazeau (2019), it becomes apparent that the heatflow varies greatly at basin scale. This seems to depend not just on the size of the grid squares over which the authors have applied their interpolation, but the exact technique used to interpolate and the input parameters they have used will lead to this variability. Consequently

326 it was decided that analysis of the range of heatflow values that are observed in the literature

327 for this area (Andrews-Speed et al., 1984; Cornelius, 1975; Davies, 2013; Evans \& Coleman, 328 1974; Harper, 1971; Leadholm et al., 1985; Lucazeau, 2019; Ritter et al., 2004) will be used to 329 define predetermined starting conditions for heatflow. By using the conclusions of these 330 existing studies, previous modelling accounting for factors such as the impact of the Curie 
depth in the area or the impact of basal heatflow, is incorporated. This gives a low-, mid- and high- case a priori surface heatflow of 60,70 and $80 \mathrm{~mW} \mathrm{~m}^{-2}$ respectively.

\subsubsection{Temperature grids \& calibration}

334 Having determined thermal conductivity and established heatflow scenarios it becomes possible to calculate three geothermal gradient scenarios for the model area. By convolving this with the subsurface depth and incorporating the bottom water temperature (BWT) (i.e., seabed temperature) an estimate of present-day subsurface temperature can be made.

338 Equation 4: $T=T_{S E A B E D}+\left(\frac{d T}{d Z} \times Z_{S U B S U R F A C E}\right)$

where $T$ is predicted temperature $\left({ }^{\circ} \mathrm{C}\right) ; T_{\text {SEABED }}$ is the temperature at seabed $\left({ }^{\circ} \mathrm{C}\right) ; d T / d Z$ is the

340 instantaneous geothermal gradient $\left({ }^{\circ} \mathrm{C} \mathrm{km}^{-1}\right.$ ) (Eq. 2); and Z SUBSURFACE is the subsurface depth

$341(\mathrm{~km})$.

342 Early studies into the geothermal aspects of the North Sea would set temperature at the 343 seafloor to a constant, for example $10{ }^{\circ} \mathrm{C}$ (Cornelius, 1975; Evans \& Coleman, 1974; Harper, 1971). Here however seafloor temperature was assigned through decadal averages from the World Ocean Atlas (WOA) dataset (Boyer et al., 2014; Locarnini et al., 2013). Using the nearest measurement node from the 0.25 -degree grid of the WOA dataset, the temperature profile 347 (hydrothermal gradient) for this was used to interpolate seafloor temperatures across the 348 seafloor within the model area. Temperatures are found to be in the range of 6 to $9{ }^{\circ} \mathrm{C}$ with seafloor temperatures in the shallower water of the UKCS averaging $7.3{ }^{\circ} \mathrm{C}$, and in the

350 relatively deeper waters to the east, these temperatures average $8.7^{\circ} \mathrm{C}$. By basing the seafloor temperatures on a decadal average, the variability of seasonal bottom water conditions and longer scale variability will be negated. This gives a baseline temperature from 
which the well readings can be seen in context to, particularly with regard to determining the geothermal gradient.

Thermograms, or temperature profiles, depicting temperature change with depth are one way of displaying the model results for each well site (Cornelius, 1975). Petrel allows for the creation of synthetic logs from a reservoir model or pillar grid. This requires resampling the temperature models into a pillar grid coincident with the extent of the area of interest. The dimensions of the individual cells of the grid, and subsequently the total number of cells constituting the entire grid are important with respect to the total compute power. The modelling results displayed here have a lateral resolution of $50 * 50 \mathrm{~m}$ (XY orientation), with the top of the model coinciding with mean sea level (MSL) and the base being set at $5.5 \mathrm{~km}$ depth. It is important to establish the base for the thermal model as this will define the interval over which geothermal gradient is calculated. This basal depth encompasses the maximum vertical depth of the wells used for calibration. Cell height was set to $20 \mathrm{~m}$, in accordance with the vertical resolution of the velocity data. For these dimensions, the entire gridded model comprises about 1.4 billion voxels.

With all the input and derived seismic attributes resampled as properties in the pillar grid, synthetic logs for each well are generated. These synthetic logs are made for the three temperature prediction volumes coincident with the three heatflow input scenarios. The

371 estimated temperature at the bottom of each well from the synthetic logs is then plotted 372 against the recorded corrected BHT (Fig. 7). Theoretically, the misfit between observed and 373 modelled temperature for each well can be used to calculate how much the heatflow input 374 for each well must be adjusted for there to be no misfit. In this way, the most representative 375 heatflow value for the area might be calibrated. 
377 The first stage of subsurface temperature modelling assumed 3 discrete heatflow parameter 378 input scenarios. In this instance, discrete values for heatflow across the model area were used 379 to simulate each temperature scenario. However, heatflow is likely not homogeneous across 380 the model area and there may be lateral variability across individual structures and preferred 381 fluid migration paths. If recorded temperatures in the wells are assumed to be correct and 382 with knowledge of the seafloor temperature, geothermal gradient can be independently computed for each well site. Additionally, if the seismic velocity derived thermal conductivity is considered valid, it becomes possible to use the 1D approximation of Fourier's Law to derive heatflow at each well location. This is the inverse problem.

386 Equation 5: $q=K_{V} \times\left(\frac{T_{B H T}-T_{S E A F L O O R}}{d Z}\right)$

Where $q$ is heatflow $\left(\mathrm{mW} \mathrm{m}^{-2}\right) ; K_{V}$ is thermal conductivity from velocity $\left(\mathrm{W} \mathrm{m}^{-1} \mathrm{~K}^{-1}\right) ; T_{B H T}$ is bottom hole temperature $\left({ }^{\circ} \mathrm{C}\right) ; T_{\text {SEAFLOOR }}$ is temperature at seafloor $\left({ }^{\circ} \mathrm{C}\right)$; and $d Z$ is the vertical depth interval $(\mathrm{km})$. Interpolating for heatflow between the wells creates a map of inversely modelled laterally varying heatflow. An inverse distance weighting (IDW) function has been used to interpolate heatflow. The values of cells in the vicinity of the processing cell (interpolated gap) are averaged, with the distance of the neighbouring cell having an inverse weighting (Watson \& Philip, 1985).

396 Calibrating the results of the temperature forward model with the different heatflow input 397 scenarios, it is likely to show different degrees of agreement. Iteratively updating the heatflow 
parameter input each time and remodelling for subsurface temperature should theoretically permit the most representative heatflow across the study area to be arrived at ultimately.

400 However, this former approach was not pursued as it was shown previously that inverse modelling (see section 4.2) allows the determination of laterally varying heatflow across the

402 model area. Convolving this heatflow with the seismically derived thermal conductivity (Eq.

4032 2), it should be possible to generate a volume of instantaneous geothermal gradient that has

404 most agreement across all the calibration wells. This thermal gradient is used to generate a 405 final temperature model (Eq. 4) that is resampled into the pillar grid and used to output 406 synthetic temperature logs. Predicted temperature from these logs at hole bottom is 407 extracted and used to calibrate against recorded BHT as before.

408 The well 31/5-7 is located due southwest of Troll A field and targets the lower Jurassic Cook 409 and Johanssen formations for injection. The targeted interval has ca.173 $\mathrm{m}$ of sandstone

410 overlain by $75 \mathrm{~m}$ of shale acting as a seal above it. Pressure data indicates no communication

411 in rocks above and below the shale, reinforcing its seal properties. With no results from this

412 well published due to its very recent completion, it was decided to use the available details 413 (well head coordinates and total depth) to simulate the temperature profile for this well using 414 our model.

\section{5. Results}

416 The results from the modelling work are presented either as seismic attribute overlays on

417 transects or by means of attribute maps on a gridded horizon. But for the purposes of 418 calibration the primary output is the synthetic temperature log data from the wells. These 419 results are discussed individually in the following section. 
The FWI interval velocity volume was converted to an average velocity volume, before

421 applying the velocity to thermal conductivity transform (Fig. 4) to produce a volume of

422 average thermal conductivity. Looking at the internal velocity derived thermal conductivity

423 structure (Fig. 5b), the direct nature of the bulk shift results in the thermal conductivity

424 variation with depth across the volume corresponding to the level of detail seen in the input

425 velocity (Fig. 5a). Cretaceous and younger Cenozoic sediment cover is seen to have relatively

426 low thermal conductivities, with a distinct increase in thermal conductivity seen in the tilted

427 fault blocks of the Viking Graben. The graben corresponds with the greatest amount of

428 overlying sediment cover and lower conductivities relative to the neighbouring rift shoulder.

429 Figure 5: Derived thermal conductivity structure

430 The forward modelling results using the predefined heatflow input scenarios are displayed on

431 the west-east transect A-A' (see Fig. 6). As expected, temperatures increase gradually with 432 depth, with no major anomalous zones seen. Cenozoic sediments are coolest with the highest

433 temperatures in the graben itself, which makes sense considering constant heatflow but 434 lower conductivities of the sediments within the graben. Isotherms are more widely spaced 435 as we move towards the Horda Platform in the east where the conductivity is greater. As 436 predicted by Fourier's Law, increasing heatflow leads to increased subsurface temperatures.

437 The direct impact of each heatflow input scenario is better visualised when cross plotting the 438 temperature extracted from each well (Fig. 7).

439 Figure 6: Forward modelling output for heatflow scenarios

440 As stated earlier, synthetic thermograms corresponding to the well path of each calibration 441 well were extracted from the predicted temperature models. The temperature at bottom 442 hole in each case has been plotted against the recorded BHT. The best fit regression through 443 each cluster of points and the gradient of this is used as a measure of the degree of agreement 
between predicted and observed values. The R-squared value, a measure of statistical validity

445 for each regression line, for all three heatflow scenarios is above the 0.7 that is regarded as

446 being the threshold for statistical reliability. Analysing the misfit between predicted BHT and

447 corrected $\mathrm{BHT}$, it is found that on average the low heatflow scenario is $0.64{ }^{\circ} \mathrm{C}$ cooler; the mid

448 heatflow scenario has average misfit $15.4{ }^{\circ} \mathrm{C}$ higher and the high heatflow scenario has an

449 average misfit of $31.3^{\circ} \mathrm{C}$ higher. With increasing heatflow, the corresponding gradient of the

450 regression line through that cluster of points also increases, as does the $\mathrm{Y}$-intercept. The

451 optimum desired gradient that would be expected for best agreement between predicted

452 and observed temperatures would verge on 1, and from this initial forward modelling it is

453 seen that the lowest heatflow scenario is closest to this. However, it is also the case that the

454 optimum regression should be seen to pass through the origin of the cross plot and increasing

455 the heatflow moves each regression further away from this.

$456 \quad$ Figure 7: Forward modelling results calibrated

457 When deriving ocean bottom heatflow across the model area through an inverse modelling

458 problem (see 4.2) (Fig. 8), gives mean heatflow of $60.05 \mathrm{~mW} \mathrm{~m}^{-2}$ and a median of $62.82 \mathrm{~mW}$

$459 \mathrm{~m}^{-2}$. The effective range of heatflow is between 40 to $70 \mathrm{~mW} \mathrm{~m}^{-2}$. Observing the heatflow

460 variation across the area (Fig 8) certain wells are seen to have much lower heatflow than their

461 immediate vicinity. Consequently, during interpolation, these wells are seen in a bulls-eye

462 zone of depressed heatflow. The most prominent of these is observed to the southwest, with

463 two wells (30/5-1 \& 30/8-2) having depressed effective heatflow. Referring to Fig. 1 these two

464 wells do not coincide with any field. The other prominent heatflow depression is found to the

465 northeast of the model area at the intersection between Troll-A and Troll-B. The north-

466 westernmost and easternmost wells (29/3-1 \& 32/4-1, respectively) (Fig. 8) influence the

467 immediate vicinity by elevating the heatflow interpolated here. 
469 The result of running a final iteration of forward modelling for temperature with the

470 continually laterally varying heatflow derived in Fig. 8 is shown in Fig. 9. We find when cross

471 plotting predicted temperatures from this final model against BHT that the general

472 distribution of points has a far tighter spread than in the previous modelling instances. The

473 average misfit between predicted $\mathrm{BHT}$ and measured $\mathrm{BHT}$ is $0.58{ }^{\circ} \mathrm{C}$. Furthermore, the best

474 fit regression through this set of points has a gradient nearly equal to 1 , and passes nearest

475 to the origin, as is expected for the model best reflecting the actual subsurface temperature.

476 Interestingly, the average of the inverse modelled heatflow as stated earlier is nearly equal

477 to the low case heatflow input scenario used in the early-stage forward modelling. Looking at

478 the distribution of well points (Fig. 9) however it is clear that there is a great disparity in the

479 two approaches. The visual impact of the two approaches is shown in Fig. 10d, e.

$480 \quad$ Figure 9: Well calibration including final temperature model

481 The result from the final iteration of the temperature model overlain with key structures is

482 shown in Fig. 10a. Running an RMS amplitude extraction for thermal conductivity on a 483 reference horizon (Fig. 10c), in this case the $\mathrm{BCU}$, it is observed that the highest thermal 484 conductivities are observed in the heart of the Viking Graben, where the BCU is deepest (Fig. 485 10b). On the flanks of the graben and eastward towards the Horda Platform, thermal conductivities are seen to decrease considerably, consistent with the increasingly shallowing

487 BCU surface at that point. Reverting to the temperature model outputs, we see the difference 488 between the initial forward modelling approach (Fig. 10d) and the final inverse modelled 489 heatflow influenced iteration (Fig. 10e). Comparing the temperatures, within the deep graben 490 for example, it is immediately apparent there is greater variation and detail discernible in 491 from this latter approach. Indeed, what is seen is that some anomalous temperature zones 
are seen in this final iteration at the northern tip of the Troll field that seem to directly correlate with the anomalous heatflow zone from the interpolation (see Fig. 8a).

Figure 10: Temperature modelling results

495 The results of simulating the thermal profile for the Northern Lights well 31/5-7 (Eos) are shown in Fig. 11, with temperature at bottom hole of $97^{\circ} \mathrm{C}$ falling well within the projected $100{ }^{\circ} \mathrm{C}$ range published on the project website (see: https://northernlightsccs.com/en/about accessed at $25 / 07 / 2020$ ). Data released by Equinor and the Norwegian government in October 2020 with preliminary results indicated temperature at the bottom of $103{ }^{\circ} \mathrm{C}$. The final well report with its $\mathrm{BHT}$ record has not yet been made public but preliminary results from the 31/5-7 prediction show a good agreement between model prediction and reality.

Figure 11: CCS well 31/5-7 modelled

\section{Discussion}

504 There are multiple corollaries of modelling for subsurface temperature in this manner. The

505 seismic led method of deriving subsurface thermal conductivity structure should enable the verification of zones of thermal blanketing (Cercone \& Pollack, 1991; Wangen, 1995). Due to

507 the direct relationship between velocity and thermal conductivity as used here, any zones of anomalously high or low velocity will be reflected in thermal conductivity anomalies. The

509 general trend contains lithologies such as sandstone, shale, limestone and crystalline rocks.

510 This excludes lithologies that deviate from our general trend such as halite, which will need

511 to be considered explicitly to represent the temperature above, within and below such anomalous bodies.

513 The benefit of the highly detailed FWI velocity model available in this area is that the velocity

514 data has been calibrated against wells in the NVG, thus ensuring the velocity model is a good 
representation of true subsurface properties and conditions. The conversion to thermal

516 conductivity and temperature provides another means of visualising the subsurface. It is of

517 critical importance to both petroleum exploration and carbon sequestration in the area. In

518 other locations such estimates would be highly beneficial to geothermal or gas storage

519 operations. It must be noted that any artefacts in the velocity data will be translated to the

520 derived thermal conductivity, instantaneous geothermal gradient and predicted temperature

521 volumes as a consequence of the direct transitions in the workflow.

\subsection{Heatflow modelling - impact and implications}

523 The validation of the inverse modelling of heatflow as an input as opposed to the use of a

524 discrete integer value heatflow input is borne out by the results. The interpolation of heatflow

525 over the $12000 \mathrm{~km}^{2}$ model area (Fig. 8) highlights the variation in heatflow magnitude laterally

526 at improved coverage compared to most existing studies. As shown earlier (Fig. 1), global and

527 regional compilations usually produce heatflow grids that are at the scale of 1-degree grid squares or larger. The lateral resolution is thus many orders of magnitude poorer than when

529 based on BHT and conductivity data. Interpolating heatflow at such fine scale might enable

530 the examination of any trends, if any, in heatflow versus features that may be hydrocarbon

531 fields, or structural trends (for example major fault networks). While there is a paucity of data

532 points in the IHFC grid coinciding with large parts of the Northern and Central North Sea, the

533 many decades of hydrocarbon exploration in the area led to numerous wells, many of which

534 have detailed records of BHT. When combined with the seismic velocity driven model to

535 ascertain thermal conductivity structure, it should allow for the possibility to fill in the large

536 gaps in the global point heatflow database, which in turn should allow for more detailed basin

537 scale heatflow studies. 
The thermal anomaly visible in the interpolated ocean bottom surface heatflow map (Fig. 8)

539 can be seen to coincide with the Troll Field (Fig. 1). Records of this thermal anomaly attribute

540 it to transient effects of uplift caused by late Quaternary deglaciation (Cornford, 1998). The

541 method used to interpolate heatflow might have an impact. IDW gives the best results when

542 the sampling is sufficiently dense with respect to the local variation being simulated (Watson

543 \& Philip, 1985). Where sampling is sparse or uneven, the interpolated result will insufficiently

544 represent the desired surface (Philip \& Watson, 1982). From the density of wells around

545 existing fields in the area, we can be sure that the IDW interpolation will reliably capture the

546 laterally varying heatflow at this local scale. Nonetheless at the edges of the model area there

547 will be some degree of uncertainty associated with the interpolated heatflow, a consequence

548 of the sampling sparseness in these regions. Kriging would be a more statistically rigorous

549 method of interpolating heatflow, but it requires a prior investigation of the spatial behaviour

550 of heatflow in the sample points. This is incumbent on a pre-existing understanding of the

551 factors influencing the modelled parameter. In a blind test the latter would not necessarily be

552 possible, and thus IDW should be satisfactory for a first order interpretation.

553 While heatflow has been derived from inverse modelling, in sedimentary basins there is a

554 thermal contribution linked to the radiogenic heat production of sediments and crustal material, and the contribution of heat from the earth's deep interior (that is mantle) (Allen \& Allen, 2013; Hasterok et al., 2011; Hasterok, 2010; Hokstad et al., 2017). The modelling here

557 estimated present-day subsurface temperatures using a steady state approximation (Eq. 1).

558 As such, a conscious decision was made to introduce as few variables as possible. Radiogenic

559 heat production would be one such variable. Its impact here has been noted but not explicitly

560 modelled. Mantle heat production is usually estimated from the Moho, whose depth in the

561 area averages roughly $30 \mathrm{~km}$ (Grad \& Tiira, 2009). Estimates of the Curie isotherm at its 
563 Kubala et al., 2003). Under the graben, Moho depth does become shallow, up to $22 \mathrm{~km}$ in 564 places (Licciardi et al., 2020). Referring to Fig. 8a, modelled heatflow is higher towards the graben centre, which suggests some correlation. With the thermal model base set at $5.5 \mathrm{~km}$, and the degree of shallowing of the Moho not exceeding $22 \mathrm{~km}$ at its shallowest point, the

567 impact of mantle heat input from a modelling perspective is considered negligible in this

568 instance. The general Moho trend in the northern North Sea has a gradual shallowing in the north-west, near the Shetland Islands (Licciardi et al., 2020). If conducting thermal modelling

570 over the whole NVG survey area, and with the basal limits for the model set sufficiently deep such that there might be a basal mantle heatflow effect due to proximity to the Moho for the

572 deepest section of the model. Future models seeking to integrate surface heatflow with a basal heatflow flux can rely on the Curie depth for constraint (Blakely, 1988). The Curie depth

574 is often seen to coincide with a compositional boundary reflecting the loss of magnetic

575 minerals in rocks (Rajaram et al., 2009) and thus can be treated as an isotherm, identifiable using magnetic geophysical methods. It should become possible then to contrast modelled

577 surface heatflow against calculated surface heatflow from past studies, allowing determination of whether the sensitivity of NVG thermal anomalies is to basal flux or thermal conductivity effects, or a combination of the two factors.

\subsection{Relevance}

The applications of this proposed workflow range from immediate usage by the hydrocarbon industry to supporting new subsurface uses aligned with the energy transition. Hydrocarbon explorationists may use the knowledge of the isotherms to help develop their petroleum 
temperature in the reservoir in order to inform reservoir engineering projects to maximise recovery. Knowledge of subsurface thermal structure is important for the nuclear waste disposal industry due to the sensitivity of the waste to thermal perturbations (Brigaud et al., 1992). From a low carbon technology solutions perspective, mapping subsurface isotherms may enable geothermal energy prospecting and the understanding of subsurface temperature will be important for CCS operations in both frontier and mature basins.

Simulating temperatures for the current CCS Northern Lights well 31/5-7 emphasises the realworld applicability of this model, both in terms of its speed of producing an estimate and its relevance in the energy transition for the future. It is important to understand the temperature conditions in $\mathrm{CO}_{2}$ storage reservoirs as the properties of the gas vary with temperature and pressure. Of these only the pressure is routinely estimated based on seismic data (Eiken et al., 2011). At higher temperatures the density of $\mathrm{CO}_{2}$ decreases, theoretically

597 allowing for a greater volume of it to be stored in a reservoir. Studies of $\mathrm{CO}_{2}$ injection into the Utsira formation (part of the Sleipner Project) have shown that reservoir temperature is a source of uncertainty as it can also impact the diffusivity of the gas within the reservoir 600 (Chadwick et al., 2006). By using the subsurface thermal model proposed here, this key uncertainty may be constrained by project planners, both giving more constraint on the volume of $\mathrm{CO}_{2}$ able to be sequestered within a reservoir, but also the ability to ascertain lateral temperature variability would enable more nuanced storage across different parts of 604 a reservoir. Finally understanding the temperature conditions and where the potential of $\mathrm{CO}_{2}$ diffusivity is highest could help mitigate the possibility of $\mathrm{CO}_{2}$ leakage.

607 use cases are also envisioned. The study of the microorganisms endemic to the deep 608 subsurface is nascent and opens up the possibility of the crust playing host to potentially great 
biodiversity and biomass (Basso et al., 2005). Limited studies into the microbial organisms

610 found in oil reservoirs have yielded surprising results. One such study in the Troll field,

611 examining the microbial diversity of produced water, indicated that these microbes were not

612 introduced as contaminants into the reservoir as a by-product of drilling; instead RNA

613 analyses and gene matching has indicated that these are a distinct genera of temperature

614 sensitive microbes that do not match existing known mesophiles or thermophiles (Dahle et

615 al., 2008). Due to the temperature dependence of these novel microbes, and the difficulty

616 with sampling, an understanding of subsurface conditions might help in providing some

617 inclination of the exact genera that can be encountered in a reservoir based on the predicted

618 temperatures from the model. Thus, it is envisioned that the proposed model can assist the

619 microbiological community as well. Bacterial remediation has been studied as a means of

620 clean up for chemical or hydrocarbon contaminated reservoirs or aquifers (Hazen, 1997).

621 Understanding of the temperature field in the subsurface can help determine how conducive

622 the conditions are to the proliferation of such organisms. From a resource perspective

623 microorganisms have been found to impact natural gas, carbon sequestration, hydrocarbons

624 or even interfere with the underground storage of nuclear waste (Christofi \& Philip, 1997).

625 7. Conclusion

626 The work outlines a novel methodology that utilises state of the art velocity model data from

627 a mature basin such as the North Viking Graben to determine present day subsurface

628 temperatures non-invasively. Forward modelling simulations underpinned by the velocity

629 data and utilising an empirical thermal conductivity transform have been calibrated against

630 recorded temperature data from oil field wells in this sector of the North Sea. Existing work using well data allows the computing of the vertical component of heatflow, in the same 
heatflow can be computed in such a manner that lateral heatflow variability coverage is improved compared to existing datasets. Using this derived heatflow to iteratively update the forward model produced a temperature model, the calibration results for which indicate the validity of this approach. To prove the real-world efficacy of this work it has been applied to a recently drilled carbon capture and sequestration well, estimating the temperature in the target reservoir to be within a $5{ }^{\circ} \mathrm{C}$ margin at $\sim 3 \mathrm{~km}$ subsurface depth, highlighting the usability and robustness of this methodology in hydrocarbon exploration and future energy

transition projects.

\section{References}

Allen, P., \& Allen, J. (2013). Basin analysis: principles and application to petroleum play assessment. In WileyBlackwell.

Andrews-Speed, C. P., Oxburgh, E. R., \& Cooper, B. A. (1984). Temperatures and DepthDependent Heat Flow in Western North Sea. American Association of Petroleum Geologists Bulletin, 68(11), 1764-1781.

Awan, A. R., Teigland, R., \& Kleppe, J. (2006). EOR survey in the North Sea. Proceedings - SPE Symposium on Improved Oil Recovery, 1, 294-309. https://doi.org/10.2523/99546-ms

Basso, O., Lascourrèges, J., Jarry, M., \& Magot, M. (2005). The effect of cleaning and disinfecting the sampling well on the microbial communities of deep subsurface water samples. Environmental Microbiology, 7(1), 13-21. https://doi.org/10.1111/j.14622920.2004.00660.x

Beardsmore, G., \& Cull, J. (2001). Crustal Heat Flow: A Guide to Measurement and Modelling. In Cambridge University Press. https://doi.org/10.1017/S0016756803218021

Becker, J. J., Sandwell, D. T., Smith, W. H. F., Braud, J., Binder, B., Depner, J., Fabre, D., Factor, J., Ingalls, S., Kim, S.-H., Ladner, R., Marks, K., Nelson, S., Pharaoh, A., Trimmer, R., Von Rosenberg, J., Wallace, G., \& Weatherall, P. (2009). Global Bathymetry and Elevation Data at 30 Arc Seconds Resolution: SRTM30_PLUS. Marine Geodesy, 32(4), 355-371. https://doi.org/10.1080/01490410903297766

Bjørlykke, K., Ramm, M., \& Saigal, G. C. (1989). Sandstone diagenesis and porosity modification during basin evolution. Geologische Rundschau, 78(1), 243-268. https://doi.org/10.1007/BF01988363

Blakely, R. J. (1988). Curie temperature isotherm analysis and tectonic implications of 664 aeromagnetic data from Nevada. Journal of Geophysical Research, 93(B10), 11817- 
666

667

668

669

670

671

672

673

674

675

676

677

678

679

680

681

682

683

684

685

686

687

688

689

690

691

692

693

694

695

696

697

698

699

700

701

702

703

704

705

Bonté, D., Van Wees, J. D., \& Verweij, J. M. (2012). Subsurface temperature of the onshore Netherlands: New temperature dataset and modelling. Geologie En Mijnbouw/Netherlands Journal of Geosciences, 91(4), 491-515. https://doi.org/10.1017/S0016774600000354

Boulanouar, A., Rahmouni, A., Boukalouch, M., Samaouali, A., Géraud, Y., Harnafi, M., \& Sebbani, J. (2013). Determination of Thermal Conductivity and Porosity of Building Stone from Ultrasonic Velocity Measurements. Geomaterials, 03(04), 138-144. https://doi.org/10.4236/gm.2013.34018

Boyer, T. P., Garcia, H. E., Locarnini, R. A., Zweng, M. M., Mishonov, A. V., Reagan, J. R., Antonov, J. I., Baranova, O. K., Biddle, M. M., Johnson, D. R., \& Paver, C. R. (2014). 2013 World Ocean Atlas Aids High-Resolution Climate Studies. Eos, Transactions American Geophysical Union, 95(41), 369-370. https://doi.org/10.1002/2014E0410002

Brigaud, F., Chapman, D. S., \& Le Douaran, S. (1990). Estimating thermal conductivity in sedimentary basins using lithologic data and geophysical well logs. American Association of Petroleum Geologists Bulletin, 74(9), 1459-1477. https://doi.org/10.1306/0C9B25011710-11D7-8645000102C1865D

Brigaud, F., Vasseur, G., \& Caillet, G. (1992). Thermal state in the north Viking Graben (North Sea) determined from oil exploration well data. Geophysics, 57(1), 69-88. https://doi.org/10.1190/1.1443190

Cercone, K. R., \& Pollack, H. N. (1991). Thermal maturity of the Michigan Basin. Special Paper of the Geological Society of America, 256, 1-12. https://doi.org/10.1130/SPE256-p1

CGG. (2019). Final Report, CGG18M01:Horda/Tampen PSDM, Offshore Norway - North Viking Graben (NVG).

Chadwick, A., Arts, R., Eiken, O., Williamson, P., \& Williams, G. (2006). Geophysical Monitoring of the $\mathrm{CO} 2$ plume at Sleipnir, North Sea. Nato Science Series: IV: Earth and Environmental Sciences, 65(Advances in the Geological Storage of Carbon Dioxide), 303-314. https://doi.org/10.1007/1-4020-4471-2_25

Christiansson, P., Faleide, J. I., \& Berge, A. M. (2000). Crustal structure in the northern North Sea: An integrated geophysical study. Geological Society Special Publication, 167(McKenzie 1978), 15-40. https://doi.org/10.1144/GSL.SP.2000.167.01.02

Christofi, N., \& Philip, J. C. (1997). European Microbiology Related to the Subsurface Disposal of Nuclear Waste. In P. S. Amy \& D. L. Haldeman (Eds.), Microbiology of the Terrestrial Deep Subsurface (pp. 267-268). CRC Press.

Copestake, P., Sims, A., Crittenden, S., Hamar, G., Ineson, J., \& Bathurst, P. (2003). The Millennium Atlas: Petroleum Geology of the Central and Northern North Sea. In D. Evans, C. Graham, A. Armour, \& P. Bathurst (Eds.), Geological Society of London. Geological Society of London. https://doi.org/https://doi.org/10.1017/S0016756803218124

Cornelius, C. D. (1975). Geothermal aspects of hydrocarbon exploration in the North Sea Area. Norges Geologiske Unders $\varnothing$ kelse Bulletin, 316, 29-67. 
Cornford, C. (1998). Source Rocks and Hydrocarbons of the North Sea. In K. W. Glennie (Ed.), Petroleum Geology of the North Sea (pp. 376-462). Blackwell Science Ltd. https://doi.org/10.1002/9781444313413.ch11

Cox, D. R., Newton, A. M. W., \& Huuse, M. (2020). An introduction to seismic reflection data: acquisition, processing and interpretation. In N. Scarselli, J. Adam, \& D. Chiarella (Eds.), Regional geology and tectonics: principles of geologic analysis (pp. 571-603). Elsevier.

Cozier, M. (2019). CCS takes centre stage. Greenhouse Gases: Science and Technology, 9(6), 1084-1086. https://doi.org/10.1002/ghg.1942

Crameri, F., Shephard, G. E., \& Heron, P. J. (2020). The misuse of colour in science communication. Nature Communications, 11(1), 5444. https://doi.org/10.1038/s41467020-19160-7

Dahle, H., Garshol, F., Madsen, M., \& Birkeland, N.-K. (2008). Microbial community structure analysis of produced water from a high-temperature North Sea oil-field. Antonie Van Leeuwenhoek, 93(1-2), 37-49. https://doi.org/10.1007/s10482-007-9177-z

Davies, J. H. (2013). Global map of solid Earth surface heat flow. Geochemistry, Geophysics, Geosystems, 14(10), 4608-4622. https://doi.org/10.1002/ggge.20271

Davison, I., \& Underhill, J. R. (2012). Tectonics and Sedimentation in Extensional Rifts. In D. Gao (Ed.), Tectonics and Sedimentation (pp. 15-42). American Association of Petroleum Geologists. https://doi.org/10.1306/13351547M1001556

Duffaut, K., Hokstad, K., Kyrkjeb, R., \& Wiik, T. (2018). A simple relationship between thermal conductivity and seismic interval velocity. Leading Edge, 37(5), 381-385. https://doi.org/10.1190/tle37050381.1

Eberhart-Phillips, D., Han, D. H., \& Zoback, M. D. (1989). Empirical relatlonshlps among seismic velocity, effective pressure, porosity, and clay content in sandstone. Geophysics, 54(1), 82-89. https://doi.org/doi.org/10.1190/1.1442580

Eiken, O., Ringrose, P., Hermanrud, C., Nazarian, B., Torp, T. A., \& Høier, L. (2011). Lessons Learned from 14 years of CCS Operations: Sleipner, In Salah and Snøhvit. Energy Procedia, 4, 5541-5548. https://doi.org/10.1016/j.egypro.2011.02.541

Esteban, L., Pimienta, L., Sarout, J., Piane, C. D., Haffen, S., Geraud, Y., \& Timms, N. E. (2015). Study cases of thermal conductivity prediction from P-wave velocity and porosity. Geothermics, 53, 255-269. https://doi.org/10.1016/j.geothermics.2014.06.003

Evans, T. R. (1977). Thermal Properties of North Sea Rocks. Log Analyst, 18(2), 3-12.

Evans, T. R., \& Coleman, N. C. (1974). North Sea geothermal gradients. Nature, 247(5435), 2830. https://doi.org/10.1038/247028a0

Færseth, R. B. (1996). Interaction of Permo-Triassic and Jurassic extensional fault-blocks during the development of the northern North Sea. Journal of the Geological Society, 153(6), 931-944. https://doi.org/10.1144/gsjgs.153.6.0931

Fichler, C., Odinsen, T., Rueslåtten, H., Olesen, O., Vindstad, J. E., \& Wienecke, S. (2011). Crustal inhomogeneities in the Northern North Sea from potential field modeling: 
762

763

764

765

766

767

768

769

770

771

772

773

774

775

776

777

778

779

780

781

782

783

Inherited structure and serpentinites? Tectonophysics, 510(1-2), 172-185. https://doi.org/10.1016/j.tecto.2011.06.026

Fossen, H., Pedersen, R. B., Bergh, S., \& Andresen, A. (2008). Creation of a mountain chain. In I. B. Ramberg, I. Bryhni, A. Nøttvedt, \& K. Rangnes (Eds.), The Making of a Land: geology of Norway (pp. 178-232). The Norwegian Geological Association.

Fuchs, S., \& Balling, N. (2016). Improving the temperature predictions of subsurface thermal models by using high-quality input data. Part 2: A case study from the Danish-German border region. Geothermics, 64, 1-14. https://doi.org/10.1016/j.geothermics.2016.04.004

Fuchs, S., \& Förster, A. (2013). Well-log based prediction of thermal conductivity of sedimentary successions: A case study from the north german basin. Geophysical Journal International, 196(1), 291-311. https://doi.org/10.1093/gji/ggt382

Galson, D. A., Wilson, N. P., Schärli, U., \& Rybach, L. (1987). A comparison of the divided-bar and QTM methods of measuring thermal conductivity. Geothermics, 16(3), 215-226. https://doi.org/10.1016/0375-6505(87)90001-0

Gautier, D. L. (2005). Kimmeridgian shales total petroleum system of the North Sea graben province. US Geological Survey.

Gegenhuber, N., \& Schoen, J. (2012). New approaches for the relationship between compressional wave velocity and thermal conductivity. Journal of Applied Geophysics, 76, 50-55. https://doi.org/10.1016/j.jappgeo.2011.10.005

Goff, J. C. (1983). Hydrocarbon generation and migration from Jurassic source rocks in the $E$ Shetland Basin and Viking Graben of the northern North Sea. Journal - Geological Society London, 140(3), 445-474. https://doi.org/10.1144/gsigs.140.3.0445

Gosnold, W., \& Panda, B. (2002). The Global Heat Flow Database of the International Heat Flow Commission. https://doi.org/http://doi.org/10.17616/R3G305

Grad, M., \& Tiira, T. (2009). The Moho depth map of the European Plate. Geophysical Journal International, 176(1), 279-292. https://doi.org/10.1111/j.1365-246X.2008.03919.x

Grevemeyer, I., \& Villinger, H. (2001). Gas hydrate stability and the assessment of heat flow through continental margins. Geophysical Journal International, 145, 647-660. https://doi.org/ISI:000169428800007

Gu, Y., Rühaak, W., Bär, K., \& Sass, I. (2017). Using seismic data to estimate the spatial distribution of rock thermal conductivity at reservoir scale. Geothermics, 66, 61-72. https://doi.org/10.1016/j.geothermics.2016.11.007

Haaland, H. J., Furnes, H., \& Martinsen, O. J. (2000). Paleogene tuffaceous intervals, Grane Field (Block 25/11), Norwegian North Sea: their depositional, petrographical, geochemical character and regional implications. Marine and Petroleum Geology, 17(1), 101-118. https://doi.org/10.1016/S0264-8172(99)00009-4

Harper, M. L. (1971). Approximate geothermal gradients in the North Sea basin. Nature, 230(5291), 235-236. https://doi.org/10.1038/230235a0 
Hartmann, A. Ã., Rath, V., \& Clauser, C. (2005). Thermal conductivity from core and well log data. International Journal of Rock Mechanics and Mining Sciences, 42(7-8 SPEC. ISS.), 1042-1055. https://doi.org/10.1016/j.jjrmms.2005.05.015

Hasterok, D. (2010). Thermal State of Continental and Oceanic Lithosphere. The University of Utah.

Hasterok, D., Chapman, D. S., \& Davis, E. E. (2011). Oceanic heat flow: Implications for global heat loss. Earth and Planetary Science Letters, 311(3-4), 386-395. https://doi.org/10.1016/j.epsl.2011.09.044

Hazen, T. C. (1997). Bioremediation. In P. S. Amy \& D. L. Haldeman (Eds.), The Microbiology of the Terrestrial Deep Subsurface (pp. 247-266). CRC Press.

Hokstad, K., Tašárová, Z. A., Clark, S. A., Kyrkjebø, R., Duffaut, K., Fichler, C., \& Wiik, T. (2017). Radiogenic heat production in the crust from inversion of gravity and magnetic data. Norsk Geologisk Tidsskrift, 97(3), 241-254. https://doi.org/10.17850/njg97-3-04

Horai, K. (1982). Thermal Conductivity of Sediments and Igneous Rocks Recovered during Deep Sea Drilling Project Leg 60. In D. M. Hussong \& S. Uyeda (Eds.), Initial Reports of the Deep Sea Drilling Project, 60 (Vol. 60, pp. 807-834). U.S. Government Printing Office. https://doi.org/10.2973/dsdp.proc.60.149.1982

Houbolt, J. J. H. C., \& Wells, P. R. A. (1980). Estimation of Heat Flow in Oil Wells Based on Relation Between Heat Conductivity and Sound Velocity. AAPG Bulletin, 65(7), 13601361.

Jones, I. F. (2018). Velocities, Imaging, and Waveform Inversion - The evolution of characterizing the Earth's subsurface. EAGE Publications.

Jorand, R., Clauser, C., Marquart, G., \& Pechnig, R. (2015). Statistically reliable petrophysical properties of potential reservoir rocks for geothermal energy use and their relation to lithostratigraphy and rock composition: The NE Rhenish Massif and the Lower Rhine Embayment (Germany). Geothermics, 53, 413-428. https://doi.org/10.1016/j.geothermics.2014.08.008

Justwan, H., Meisingset, I., Dahl, B., \& Isaksen, G. H. (2006). Geothermal history and petroleum generation in the Norwegian South Viking Graben revealed by pseudo-3D basin modelling. Marine and Petroleum Geology, 23(8), 791-819. https://doi.org/10.1016/j.marpetgeo.2006.07.001

Kubala, M., Bastow, M., Thompson, S., Scotchman, I., \& Oygard, K. (2003). Geothermal regime, petroleum generation and migration. In D Evans, C. Graham, A. Armour, \& P. Bathurst (Eds.), The Millenium Atlas: Petroleum Geology of the Central and Northern North Sea (pp. 285-315). The Geological Society of London.

Landrø, M., Solheim, O. A., Hilde, E., Ekren, B. O., \& Strønen, L. K. (1999). The Gullfaks 4D seismic study. Petroleum Geoscience, 5(3), 213-226. https://doi.org/10.1144/petgeo.5.3.213

Leadholm, R. H., Ho, T. T. Y., \& Sahai, S. K. (1985). Heat flow, geothermal gradients and maturation modelling on the Norwegian continental shelf using computer methods. In Petroleum Geochemistry in Exploration of the Norwegian Shelf (pp. 131-143). Springer 
826

827

828

829

830

831

832

833

834

835

836

837

838

839

840

841

842

843

844

845

846

847

848

849

850

851

852

853

854

855

856

857

858

859

860

861

862

863

864

Lee, M. W. (2003). Elastic properties of overpressured and unconsolidated sediments. In U.S. Geological Survey Bulletin (Vol. 2214). https://pubs.er.usgs.gov/publication/b2214

Licciardi, A., England, R. W., Piana Agostinetti, N., \& Gallagher, K. (2020). Moho depth of the British Isles: a probabilistic perspective. Geophysical Journal International, 221(2), 13841401. https://doi.org/10.1093/gji/ggaa021

Lister, C. R. B. (1972). On the Thermal Balance of a Mid-Ocean Ridge. Geophysical Journal International, 26(5), 515-535. https://doi.org/10.1111/j.1365-246X.1972.tb05766.x

Locarnini, R. A., Mishonov, A. V, Antonov, J. I., Boyer, T. P., Garcia, H. E., Baranova, O. K., Zweng, M. M., Paver, C. R., Reagan, J. R., Johnson, D. R., Hamilton, M., \& Seidov, D. (2013). WORLD OCEAN ATLAS 2013: Temperature Volume 1 (Vol. 1, Issue NOAA Atlas NESDID 81). https://doi.org/10.7289/V55X26VD

Løseth, H., Øygarden, B., Nygård, A., \& Raulline, B. (2016). Reply to Discussion on 'Late Cenozoic geological evolution of the northern North Sea: development of a Miocene unconformity reshaped by large-scale Pleistocene sand intrusion', Journal of the Geological Society , 170, 133-145 [Article]. Journal of the Geological Society, 173(2), 394-397. https://doi.org/10.1144/jgs2015-104

Løseth, H., Raulline, B., \& Nygård, A. (2013). Late Cenozoic geological evolution of the northern North Sea: development of a Miocene unconformity reshaped by large-scale Pleistocene sand intrusion. Journal of the Geological Society, 170(1), 133-145. https://doi.org/10.1144/jgs2011-165

Lucazeau, F. (2019). Analysis and Mapping of an Updated Terrestrial Heat Flow Data Set. Geochemistry, Geophysics, Geosystems, 20(8), 4001-4024. https://doi.org/10.1029/2019GC008389

Lucazeau, F., \& Le Douaran, S. (1985). The blanketing effect of sediments in basins formed by extension: a numerical model. Application to the Gulf of Lion and Viking graben. Earth and Planetary Science Letters, 74(1), 92-102. https://doi.org/10.1016/0012$821 \times(85) 90169-4$

Lucazeau, Francis, Brigaud, F., \& Bouroullec, J. L. (2004). High-resolution heat flow density in the lower Congo basin. Geochemistry, Geophysics, Geosystems, 5(3), Q03001. https://doi.org/10.1029/2003GC000644

Mareschal, J., \& Jaupart, C. (2013). Radiogenic heat production, thermal regime and evolution of continental crust. Tectonophysics, 609, 524-534. https://doi.org/10.1016/j.tecto.2012.12.001

Mavko, G., Mukerji, T., \& Dvorkin, J. (2009). The rock physics handbook : tools for seismic analysis of porous media (T. Mukerji 1965-, J. Dvorkin 1953-, T. Mukerji 1965- author, \& J. Dvorkin 1953- author (eds.); 2nd ed.). Cambridge : Cambridge University Press.

Meert, J. G., \& Torsvik, T. H. (2003). The making and unmaking of a supercontinent: Rodinia revisited. Tectonophysics, 375(1-4), 261-288. https://doi.org/10.1016/S00401951(03)00342-1 
Mielke, P., Bär, K., \& Sass, I. (2017). Determining the relationship of thermal conductivity and compressional wave velocity of common rock types as a basis for reservoir characterization. Journal of Applied Geophysics, 140, 135-144. https://doi.org/10.1016/j.jappgeo.2017.04.002

Nadeau, P. H. (2011). Earth's energy "Golden Zone": a synthesis from mineralogical research. Clay Minerals, 46(1), 1-24. https://doi.org/10.1180/claymin.2011.046.1.1

Nottvedt, A., Gabrielsen, R. H., \& Steel, R. J. (1995). Tectonostratigraphy and sedimentary architecture of rift basins, with reference to the northern North Sea. Marine and Petroleum Geology, 12(8), 881-901. https://doi.org/10.1016/0264-8172(95)98853-W

Philip, G. M., \& Watson, D. F. (1982). A Precise Method for Determining Contoured Surfaces. The APPEA Journal, 22(1), 205-212. https://doi.org/doi.org/10.1071/AJ81016

Pimienta, L., Klitzsch, N., \& Clauser, C. (2018). Comparison of thermal and elastic properties of sandstones: Experiments and theoretical insights. Geothermics, 76(June), 60-73. https://doi.org/10.1016/j.geothermics.2018.06.005

Pollack, H. N., Hurter, S. J., \& Johnson, J. R. (1993). Heat flow from the Earth's interior: Analysis of the global data set. Reviews of Geophysics, 31(3), 267. https://doi.org/10.1029/93RG01249

Popov, Y. A., Pribnow, D. F. C., Sass, J. H., Williams, C. F., \& Burkhardt, H. (1999). Characterization of rock thermal conductivity by high-resolution optical scanning. Geothermics, 28(2), 253-276. https://doi.org/10.1016/S0375-6505(99)00007-3

Popov, Y., Tertychnyi, V., Romushkevich, R., Korobkov, D., \& Pohl, J. (2003). Interrelations Between Thermal Conductivity and Other Physical Properties of Rocks: Experimental Data. Pure and Applied Geophysics, 160(5), 1137-1161. https://doi.org/10.1007/PL00012565

Posamentier, H. W. (2004). Seismic Geomorphology: Imaging Elements of Depositional Systems from Shelf to Deep Basin Using 3D Seismic Data: Implications for Exploration and Development. Geological Society, London, Memoirs, 29(1), 11-24. https://doi.org/10.1144/GSL.MEM.2004.029.01.02

Prada, M., Lavoué, F., Saqab, M. M., O’Reilly, B. M., Lebedev, S., Walsh, J. J., \& Childs, C. (2019). Across-axis variations in petrophysical properties of the North Porcupine Basin, offshore Ireland: New insights from long-streamer traveltime tomography. Basin Research, 31(1), 59-76. https://doi.org/10.1111/bre.12308

Pribnow, D. F. C., Kinoshita, M., \& Stein, C. . (2000). Thermal data collection and heat flow recalculations for ODP Legs 101-180. In Institute for Joint Geoscientific Research. http://www-odp.tamu.edu/publications/heatflow/

Purvis, S., Caughtry, N., Mann, J., \& Rumyantseva, A. (2018). Northern Viking Graben Well Study (Issue 10592).

Rajaram, M., Anand, S. P., Hemant, K., \& Purucker, M. E. (2009). Curie isotherm map of Indian subcontinent from satellite and aeromagnetic data. Earth and Planetary Science Letters, 281(3-4), 147-158. https://doi.org/10.1016/j.epsl.2009.02.013 
905

906

907

908

909

910

911

912

913

914

915

916

917

918

919

920

921

922

923

924

925

926

927

928

929

930

931

932

933

934

935

936

937

938

939

940

941

942

Ritter, U., Zielinski, G. W., Weiss, H. M., Zielinski, R. L. B., \& Sættem, J. (2004). Heat flow in the Vøring Basin, Mid-Norwegian Shelf. Petroleum Geoscience, 10(4), 353-365. https://doi.org/10.1144/1354-079303-616

Rüpke, L. H., Schmalholz, S. M., Schmid, D. W., \& Podladchikov, Y. Y. (2008). Automated thermotectonostratigraphic basin reconstruction: Viking Graben case study. AAPG Bulletin, 92(3), 309-326. https://doi.org/10.1306/11140707009

Sarkar, A. D. (2020). Reflection Seismic Thermometry [University of Manchester]. https://doi.org/10.31237/osf.io/fk7pb

Sarkar, A. D., \& Huuse, M. (2018). Subsurface Temperature Prediction From Seismic Measurements: A 3-D Seismic Case Study From The Lüderitz Basin, Offshore Namibia. AAPG International Conference and Exhibition. https://www.searchanddiscovery.com/abstracts/html/2018/ice2018/abstracts/296533 7.html

Sarkar, A. D., \& Huuse, M. (2021). Thermal regime of Blake Ridge using seismic and borehole data. Geochemistry, Geophysics, Geosystems, (in prep.), 1-41. https://doi.org/doi.org/10.1002/essoar.10506898.1

Schön, J. H. (2015a). Appendix. In Physical Properties of Rocks (Vol. 65, Issue 1995, pp. 445453). https://doi.org/10.1016/B978-0-08-100404-3.10000-9

Schön, J. H. (2015b). Thermal Properties. In Developments in Petroleum Science (Vol. 65, pp. 369-414). https://doi.org/10.1016/B978-0-08-100404-3.00009-3

The GEBCO_2019 Grid - a continuous terrain model of the global oceans and land. (2019). In GEBCO Bathymetric Compilation Group. British Oceanographic Data Centre, National Oceanography Centre, NERC, UK. https://doi.org/10.5285/836f016a-33be-6ddc-e053$6 \mathrm{c} 86 \mathrm{abc0788e}$

Velde, B. (1996). Compaction trends of clay-rich deep sea sediments. Marine Geology, 133(34), 193-201. https://doi.org/10.1016/0025-3227(96)00020-5

Wangen, M. (1995). The blanketing effect in sedimentary basins. Basin Research, 7(4), 283298. https://doi.org/10.1111/j.1365-2117.1995.tb00118.x

Warner, M., Ratcliffe, A., Nangoo, T., Morgan, J., Umpleby, A., Shah, N., Vinje, V., Štekl, I., Guasch, L., Win, C., Conroy, G., \& Bertrand, A. (2013). Anisotropic 3D full-waveform inversion. Geophysics, 78(2), R59-R80. https://doi.org/10.1190/geo2012-0338.1

Watson, D. F., \& Philip, G. M. (1985). A refinement of inverse distance weighted interpolation. Geoprocessing, 2(4), 315-327.

Zamora, M., Vo-Thanh, D., Bienfait, G., \& Poirier, J. P. (1993). An empirical relationship between thermal conductivity and elastic wave velocities in sandstone. Geophysical Research Letters, 20(16), 1679-1682. https://doi.org/10.1029/92GL02460

Ziegler, P. A. (1992). North Sea rift system. Tectonophysics, 208(1-3), 55-75. https://doi.org/10.1016/0040-1951(92)90336-5 


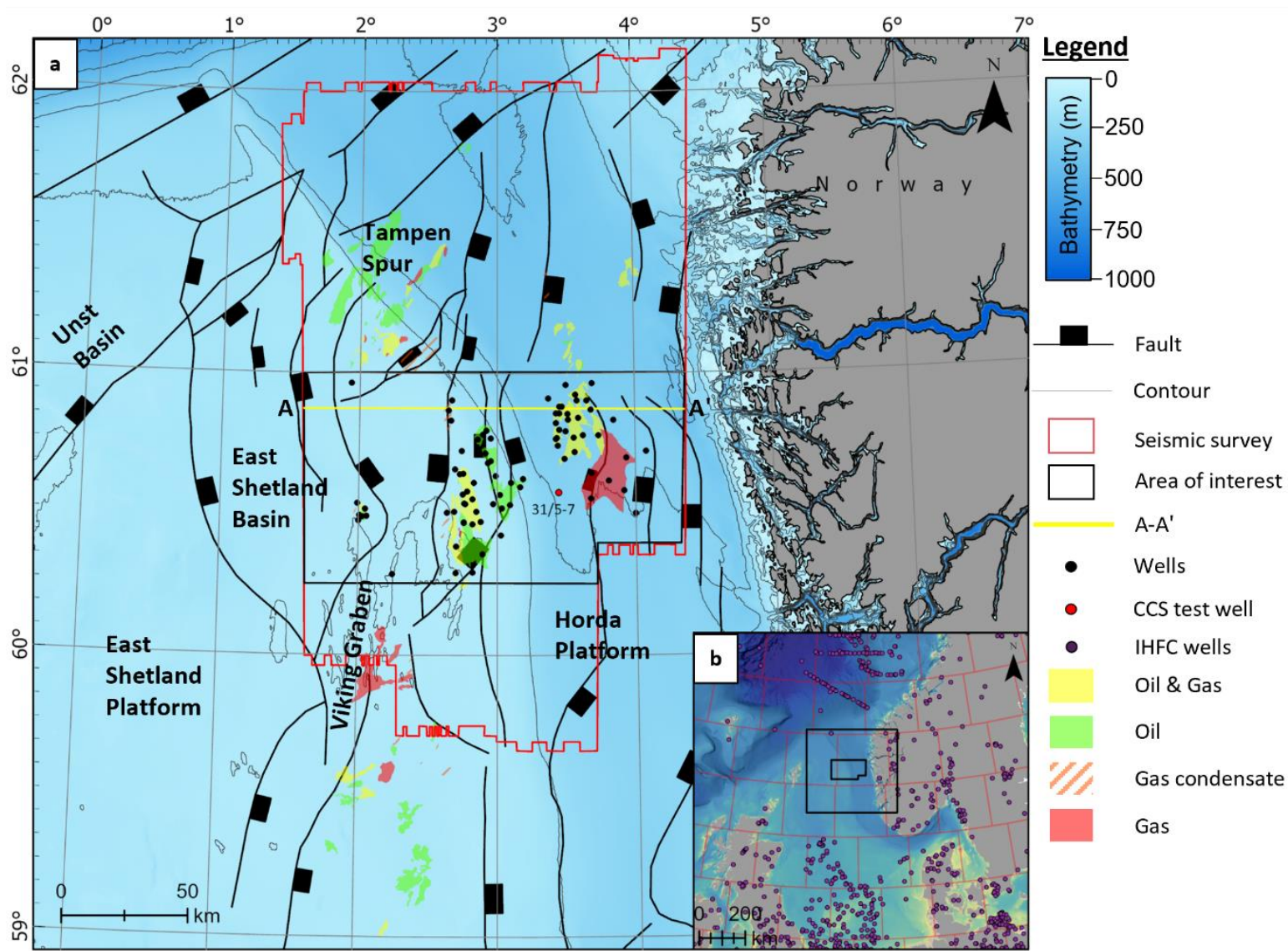

945

946

947

948

949

950

951

952

953

954

955

956

957
Figure 1: (a) Study area in the northern North Sea outlining the extent of the CGG NVG survey (displayed in red) offshore the Norwegian continental shelf with structural features displayed from (Færseth, 1996). Transect A-A' based on NVG type section (Copestake et al., 2003). Exploration wells displayed are used for calibration. Northern Lights CCS test well 31/5-7 also displayed (red circle) (between Brage and Troll fields). Bathymetry from Generalised Bathymetric Chart of the Oceans (GEBCO) (Becker et al., 2009; "The GEBCO_2019 Grid - a continuous terrain model of the global oceans and land.," 2019). (b) Existing heatflow data from the IHFC (purple points) shows a scarcity of data in the model area (Gosnold \& Panda, 2002). Relying on published heatflow grids such as the Davies (2013) shown above (red grid) demonstrates the coarseness of the data when compared to the scale of the model area (Davies, 2013). 

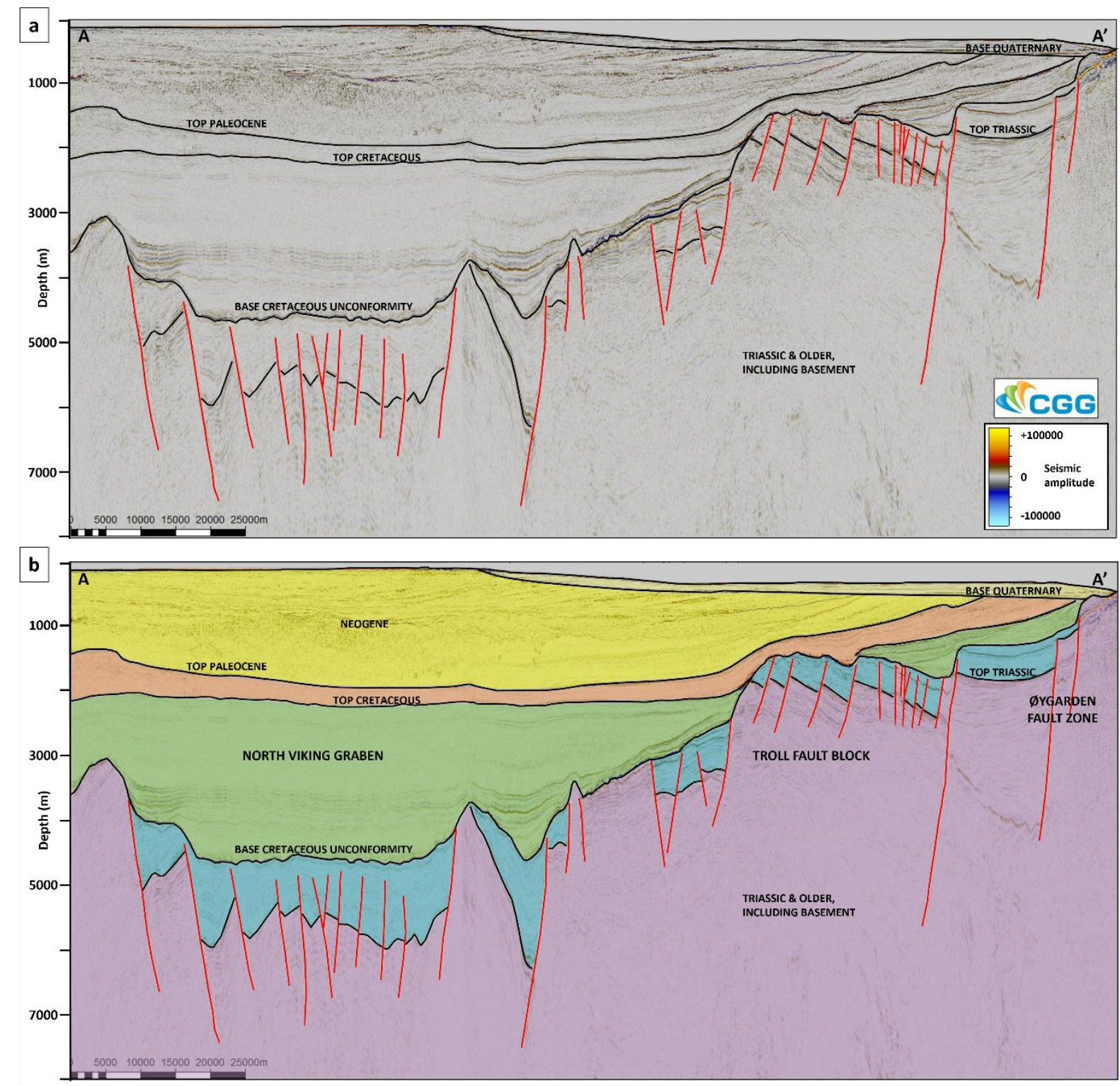

Figure 2: (a) East West transect A-A' displaying reflection seismic data, annotated with

960 major chronostratigraphic surfaces and structures of note. (b) Overlay of major intervals

961 highlighting the geometry of the NVG in the west of the model area, with tilted fault blocks

962 apparent. The study area is bounded to the west by the East Shetland Basin, with the eastern

963 limits coinciding with the Horda platform. Adapted from (Copestake et al., 2003). 


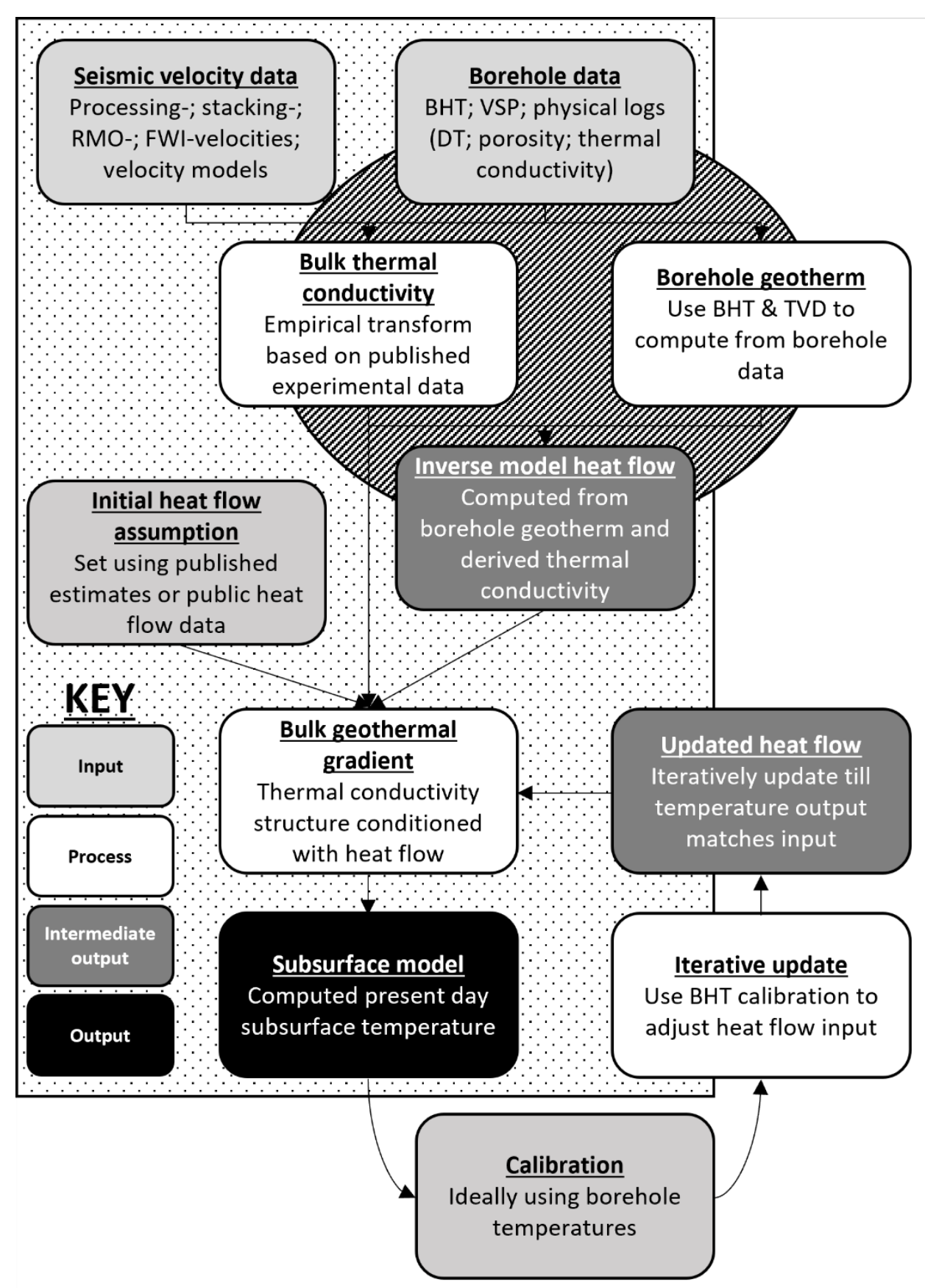

966 Figure 3: Model building workflow displayed in terms of input, processing steps and

967 outputs/deliverables. There are two main pathways, a forward modelling pathway

968 (demarcated with the dotted background polygon) where seismic data is used to simulate

969 BHTs; and an inverse modelling pathway (demarcated with the hashed background polygon)

970 where BHTs are used to determine the heatflow conditions needed for it. This allows for an

971 iterative final forward modelling pathway utilising the derived heatflow to arrive at a

972 subsurface temperature model representative of present-day conditions. 


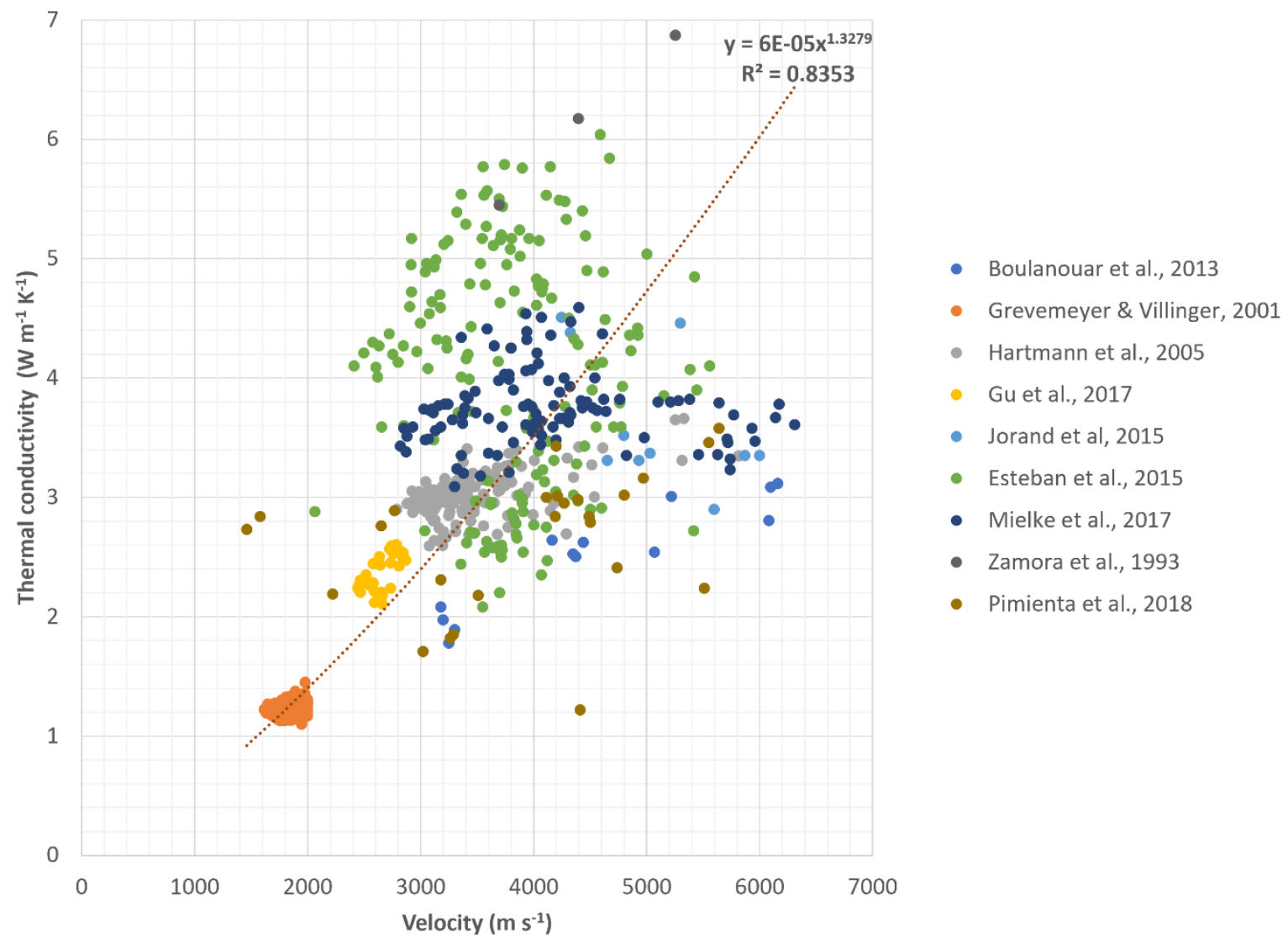

975 Figure 4: Bulk shift transform from velocity to thermal conductivity derived from

976 experimental data published in the literature. All points displayed are wet samples with

977 laboratory measurements of both velocity and thermal conductivity having been done with

978 similar tools. This is to both reflect the presence of fluids in the subsurface and to also reduce 979 the variables between displayed data respectively. 


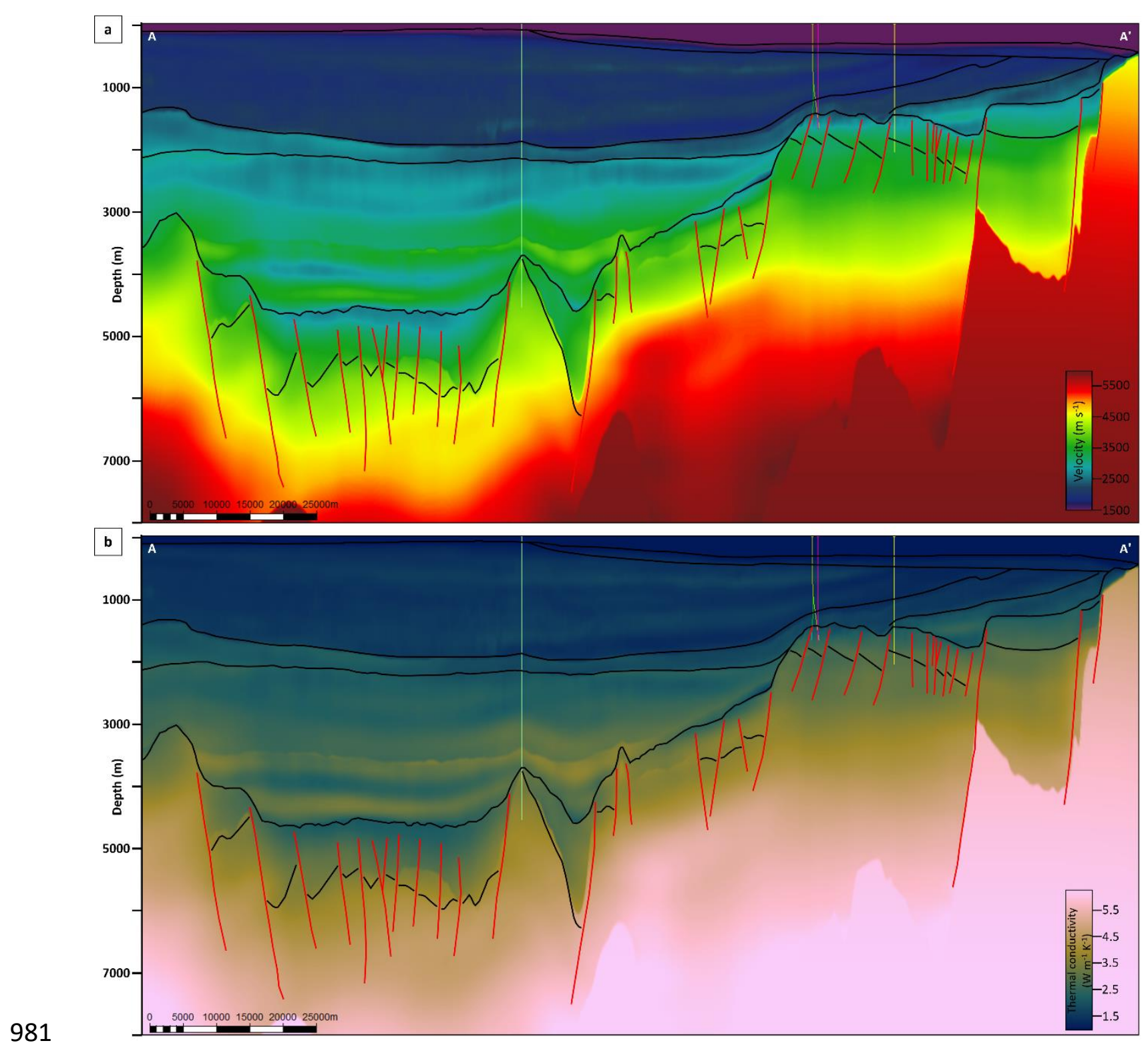

982 Figure 5: (a) Interval velocities with wells displayed. (b) Instantaneous thermal conductivity 983 from interval velocities using scientific colour bar (Crameri et al., 2020). 

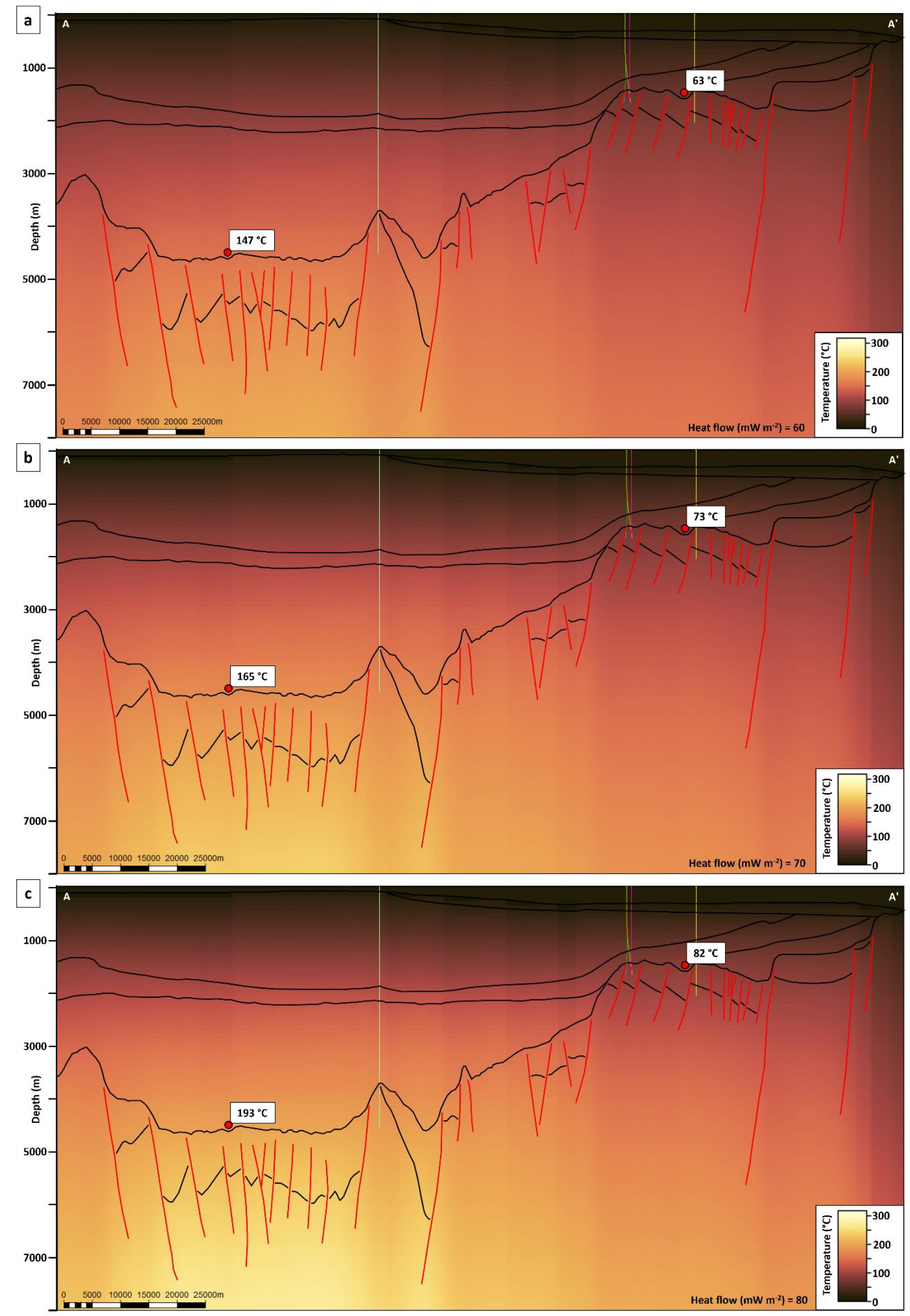

Figure 6: Forward modelling temperature prediction profiles with transect $A-A^{\prime}$ overlain for 987 (a) low case $\left(60 \mathrm{~mW} \mathrm{~m}^{-2}\right)$; (b) mid case $\left(70 \mathrm{~mW} \mathrm{~m}^{-2}\right)$; \& (c) high case $\left(80 \mathrm{~mW} \mathrm{~m}^{-2}\right)$ heatflow 
scenarios respectively. Temperature readings in the graben centre and on the graben flank are shown for reference. Highest temperatures are observed in the heart of the graben.

990 Block like appearance is an artefact of the dimensions of the individual voxels comprising the 991 thermal model pillar grid used to represent the subsurface.

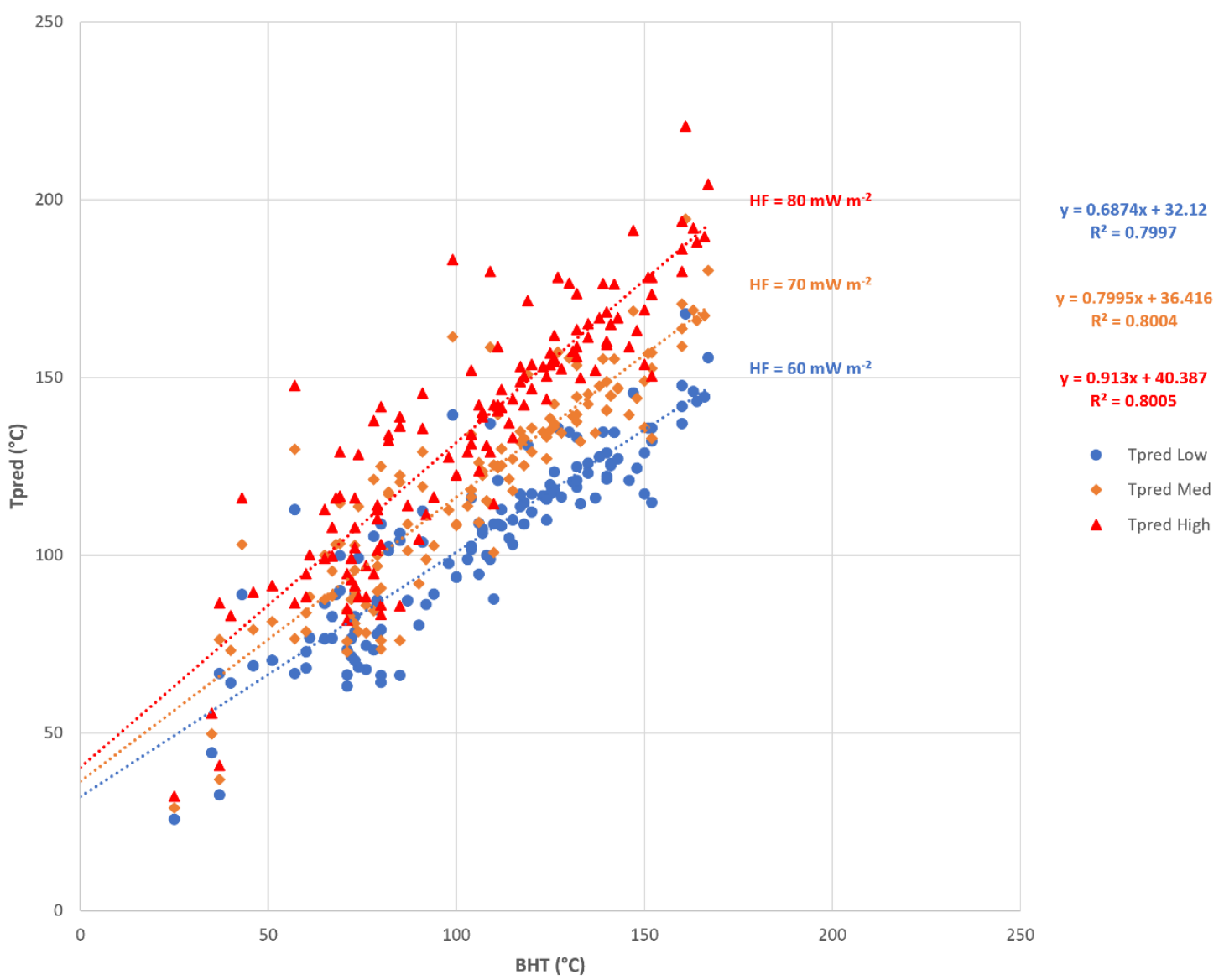

994 Figure 7: Cross plot of BHT against predicted temperatures (Tpred) for each of the three 995 forward modelling starting conditions for heatflow (low; mid and high case corresponding to 996 60; 70 and $80 \mathrm{~mW} \mathrm{~m}^{-2}$ respectively). With increasing input heatflow a corresponding increase is seen in the gradient of the regression line through that set of points. 


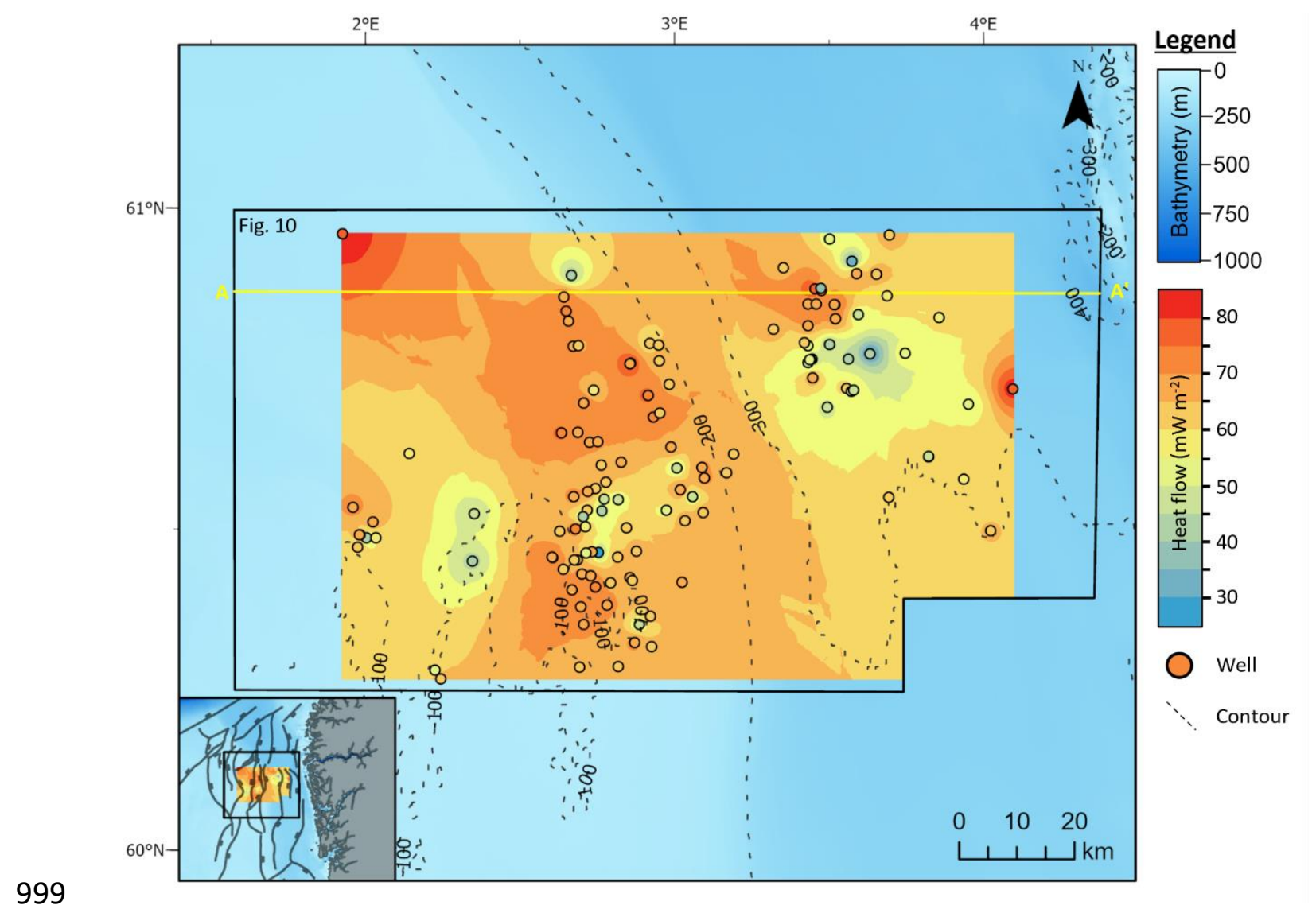

1000 Figure 8: Inverse modelling of heatflow at each well location from BHT and TVD. This data is 1001 used to interpolate heatflow across the model area. Interpolated heatflow shows lateral 1002 variability at much higher resolution than published global grids. 


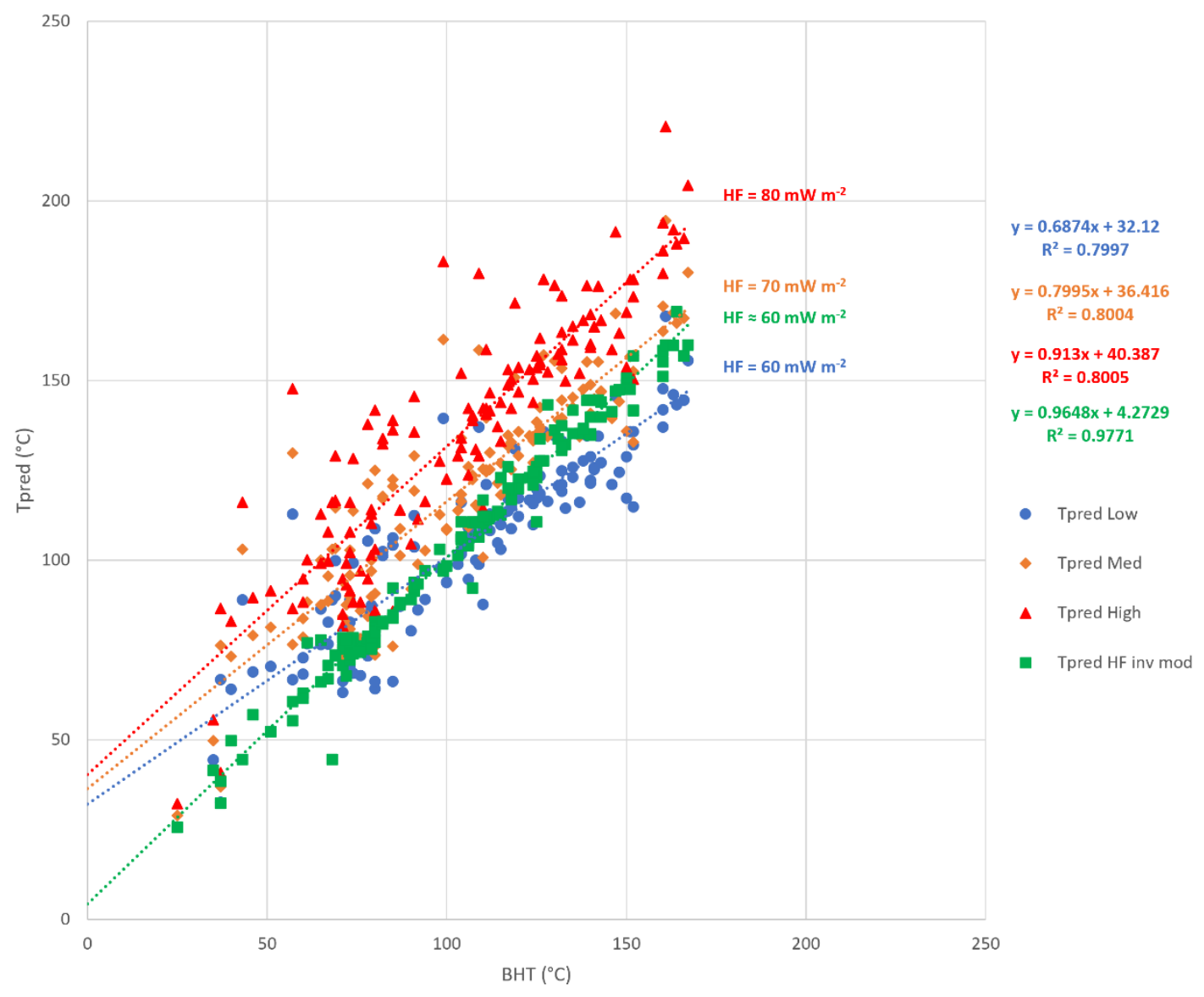

Figure 9: Cross plot of BHT against predicted temperatures (Tpred) with model results using 1006 inverse modelling of heatflow across the area displayed (green squares). R-squared for this 1007 regression suggests a good statistical fit, the results having a gradient verging on 1:1 as 1008 would be expected for results best reflecting the actual subsurface temperature conditions. 1009 Furthermore, the spread of points is much narrower for this modelling outcome. 

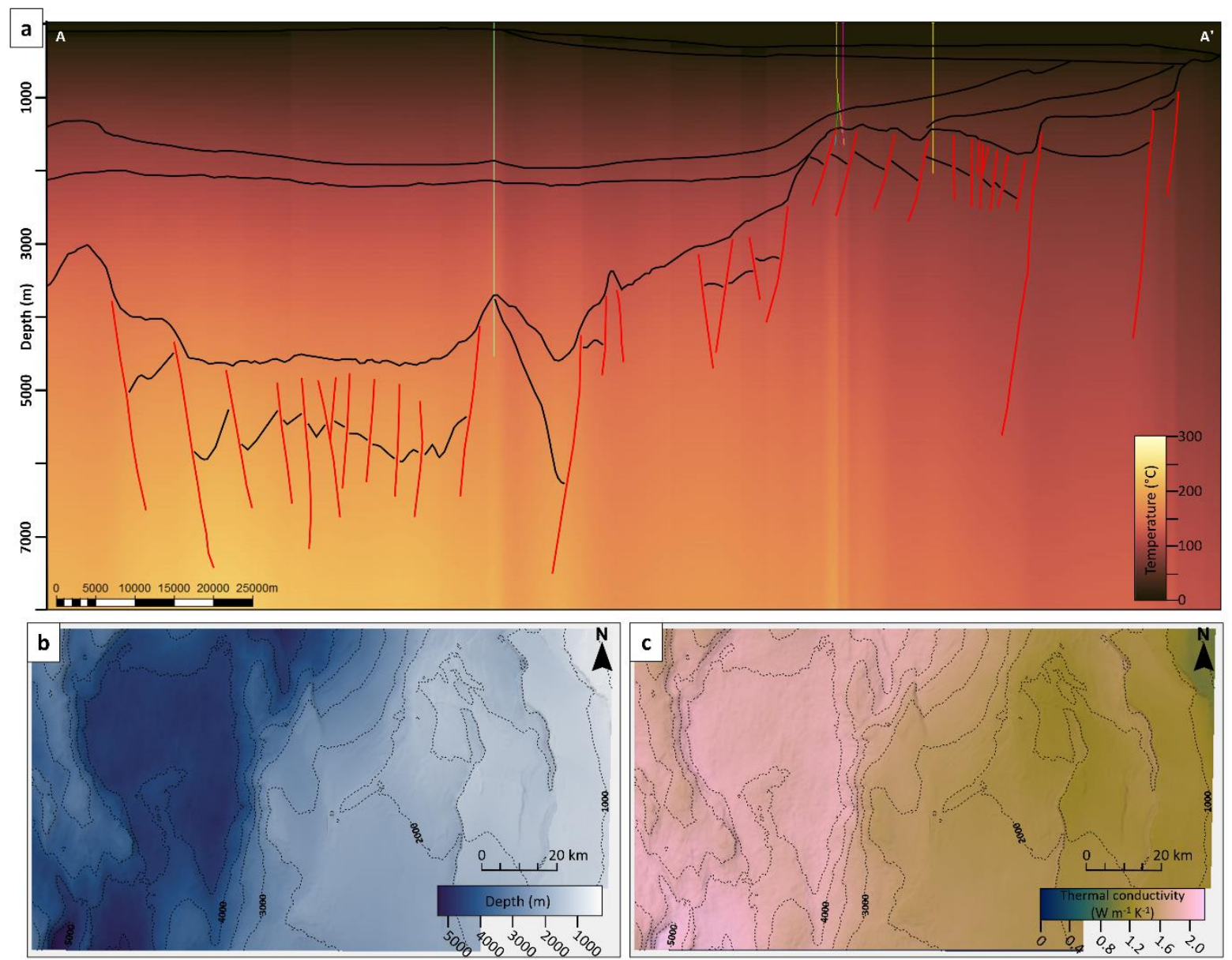

1011

1012

1013

1014

1015

1016

1017

1018

1019

1020

1021

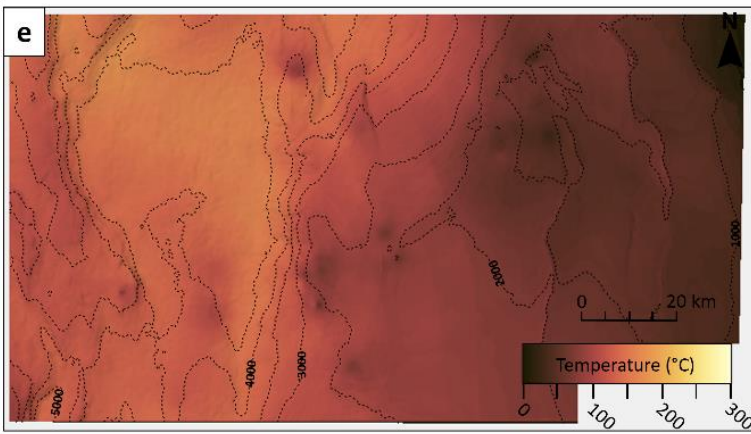

Figure 10: (a) Final temperature model produced using inverse modelling of heatflow overlain on transect $A-A^{\prime}$ (with well paths and BCU displayed). (b) BCU in depth with $500 \mathrm{~m}$ interval contours shown. (c) RMS amplitude extraction of derived thermal conductivity at $B C U$. Where $B C U$ is interpreted to shallow towards the northeast, there are correspondingly low conductivities that reflect Quaternary sediments in this region instead. (d) Low case prediction of temperature along $B C U$. (e) Final temperature prediction using inverse modelled heatflow along BCU. Comparing with (d) some differences are apparent. Bulls eye like temperature anomalies in the northeast are likely the translation of the interpolated heatflow (see Fig. 8). 


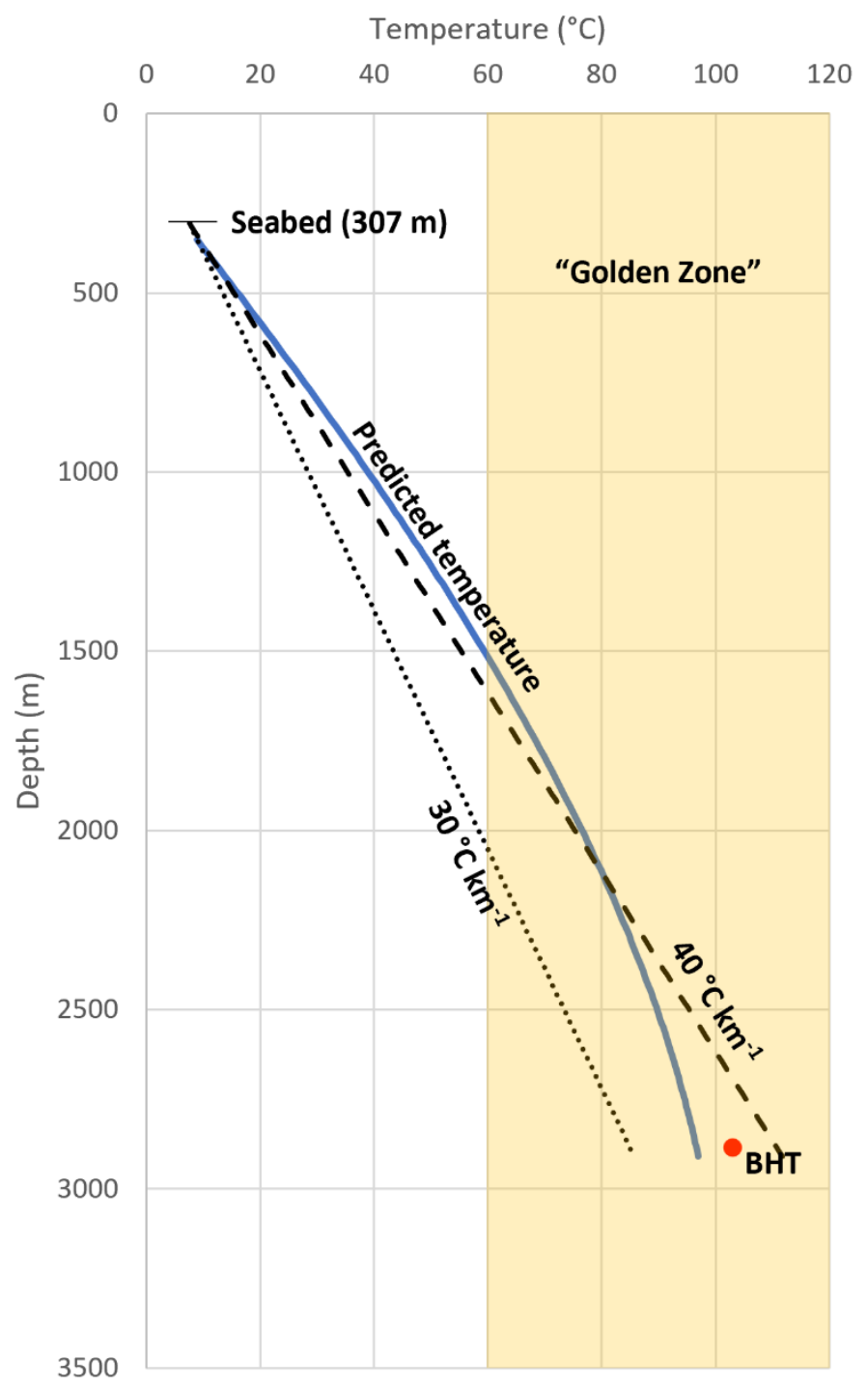

Figure 11: Modelled subsurface temperature at well 31/5-7 (see Fig. 1) as part of the Northern Lights CCS project. "Golden zone" for sandstone reservoirs is also displayed for context. BHT displayed is from October 2020 data release of preliminary results, indicating that prediction is in close agreement with what was discovered downhole (prediction is offset by $6{ }^{\circ} \mathrm{C}$ to reported BHT). Also shown are the temperature profiles taken from seabed assuming a constant linear geothermal gradient. Typically used geothermal gradients in basin modelling are $30{ }^{\circ} \mathrm{C} \mathrm{km}^{-1}$ (dotted line) and $40{ }^{\circ} \mathrm{C} \mathrm{km}^{-1}$ (dashed line). These are displayed to show how much subsurface temperature predictions may vary using standard processes, particularly at bottom hole (up to $\pm 13^{\circ} \mathrm{C}$ ). 


\begin{tabular}{|c|c|c|}
\hline Source & $\begin{array}{l}\text { Geothermal gradient } \\
\left({ }^{\circ} \mathrm{C} / \mathbf{k m}\right)\end{array}$ & Heatflow ( $\left.\mathrm{mW} \mathrm{m}^{-2}\right)$ \\
\hline (Harper, 1971) & 29.7 & $49.8-62.0$ \\
\hline (Evans, 1977) & & 63 \\
\hline (Brigaud et al., 1992) & $31.8-36.3$ & $50-65$ \\
\hline (Leadholm et al., 1985) & $30-35$ & $58.6-67$ \\
\hline (Justwan et al., 2006) & & 52.3 \\
\hline (Cornford, 1998) & & $60-82$ \\
\hline $\begin{array}{l}\text { (Lucazeau \& Le Douaran, } \\
\text { 1985) }\end{array}$ & & 65 \\
\hline (Goff, 1983) & 32 & $57-65$ \\
\hline (Rüpke et al., 2008) & $30-40$ & \\
\hline (Ritter et al., 2004) & & 65 \\
\hline
\end{tabular}

1034 Table A.1: Some examples of reported geothermal gradient and heatflow for the NVG and 1035 surrounding basins from the literature.

1036 